Historic, Archive Document

Do not assume content reflects current scientific knowledge, policies, or practices. 


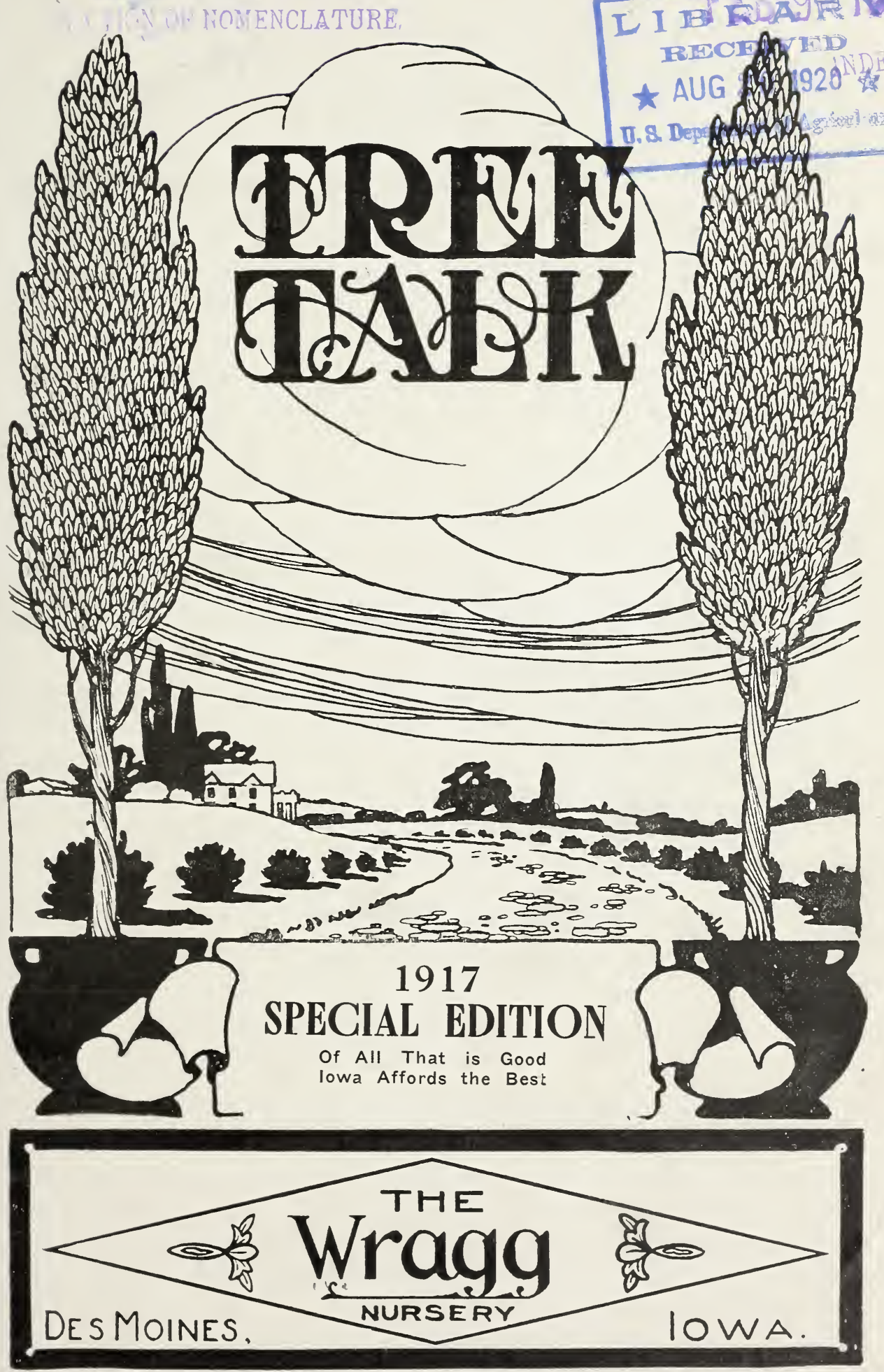


\section{The Mission of this Catalogue}

With the experience of almost a life time behind us-our Company being one of the oldest of its kind in Iowa-with an intimate knowledge of the soil, climate and conditions of this part of our country, with a desire to impart that knowledge to others and to encourage the raising of more and better fruit than has been the rule in this section, with the hope that we can by it stimulate the growing desire of our people for more beautiful home surroundings by pointing out to them the proper kinds of trees, vines, shrubs and flowers to plant, we send out this new Catalog on its mission of helpfulness, with a determination to make the name of our Company a synonym for all that is best in nursery stock, knowing that good stock, truthfully described and sold at reasonable prices, is bound to bring success.

Carrying out this rule, we propose to be sure that every item of stock, whether it be fruit, shade or ornamental trees, vines or plants, be first-class in every respect and true to the name. Our descriptions are short and accurate, and may be relied upon, and our prices are as low as it is possible to make them, taking into consideration the size and quality of the stock we supply.

Our manager, M. J. Wragg, is looked upon as one of the best authorities in the trade in the Northwest. He was one of the Jury of Awards on Fruit in the Pomological Section of the Louisiana Purchase Exposition, is Agricultural Editor of the newspapers controlled by the Western Newspaper Union, Director of the Department of Agriculture of Iowa, Ex-President of the Iowa Horticultural Society, director of an experiment station, is connected with the Frisco Orchard Company, of Kansas City, Mo., as Horticultural Superintendent and one of the Board of Directors, and was awarded a special gold medal at the St. Louis Fair for the largest and best collection of Cherries and Plums from the State of Iowa.

Our location in the midst of the great Mississippi valley, furnishes a quality of soil best suited to produce the healthiest conditions of growth, with solid, firm texture of wood, with abundant fibrous roots, so necessary to successful transplanting enables us to offer the products of our nurseries with entire confidence to planters in all sections of the country. In our nearly thirty years' experience in growing nursery stock in central Iowa, we have experimented with nearly all kinds of fruits and ornamentals, and are able to offer the benefit of our experience to our customers.

Our shipping facilities are first-class, being situated, as we are, in the center of the state, at Des Moines, where all the railroads center, which gives us excellent facilities for handling freight or express to every point in the state.

In our extensive collection of nursery stock herein offered, we call your special attention to the Wragg Cherry, Saylor Cherry, Stoddard Plum and lowa Raspberry. These varieties are already being extensively propagated through the East and South, and have now become standard varieties. The Stoddard stands at the head of our large first-class native plums. It is a prolific bearer, of excellent flavor. The lowa Raspberry was introduced by us, and wherever it is planted and becomes known, everyone speaks of it with the highest words of praise. We are also growing more new varieties of Evergreens, Currants, and especially Roses and Herbaceous Plants.

We invite your careful reading of the following pages, and solicit your business. Our best customers are those who know us best. We have nothing to conceal-no trade secrets. WE DEAL DIRECTLY WITH THE PUBLIC, and are always glad to welcome customers to our nursery, where we will take pleasure in showing them all features of interest, and will cheerfully answer all questions.

Thanking our old friends for past favors, a continuance of which we hope to merit, and hoping to make many new ones for our mutual benefit, we remain,

$$
\text { Yours very truly, }
$$

THE WRAGG NURSERY COMPANY, 


\section{APPLES}

The apple is universally recognized as the most desirable fruit of the United States, because of its great varieties of delicious flavors, nutritious qualities and nutrative value. Whether as commercial crop or for the satisfaction of the family, a well selected orchard of a few varieties is a most desirable investment that any land owner can place on his premises.

We recommend the planting of a few thrifty trees from one to three years old and from four to five feet high as such are more safely handled than older and larger trees.

\section{Summer Apples}

Benoni-Pale yellow, marked with dark crimson; fine bloom; juicy, crisp, acid; medium size; tree a medium grower; bears young and profusely; August.

Early Harvest-Medium to large; pale vellow; fine flavor. Tree moderate, erect grower, and a good bearer. A beautiful and excellent variety for dessert and kitchen.

Duchess of oldenburg-Large size, roundish; streaked with red and yellow; flesh whitish; juicy; flavor sprightly, subacid; market variety. Tree a vigorous grower; very hardy; succeeds in northwest where many kinds fail. August-September-October

Golden Sweet-A large, handsome, yellow apple; fine; sweet; good for market. Tree rather spreading and irregular. A free grower and productive; August-September.

Liveland (Liveland Raspberry)-Color orange-yellow, striped, splashed and shaded with red, showing gray dots through the color; flesh light yellow of ten stained with red, fine, tender, juicy; core medium open; flavor sub-acid, good; season,

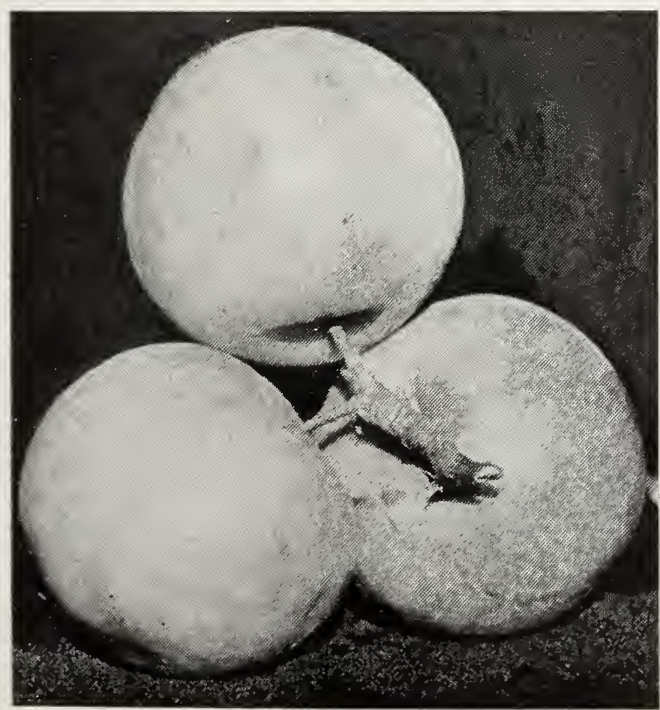

Yellow Transparent
August. There is no apple East or West of better quality than the Liveland. The tree is perfect and a good bearer; the fruit is handsomely colored.

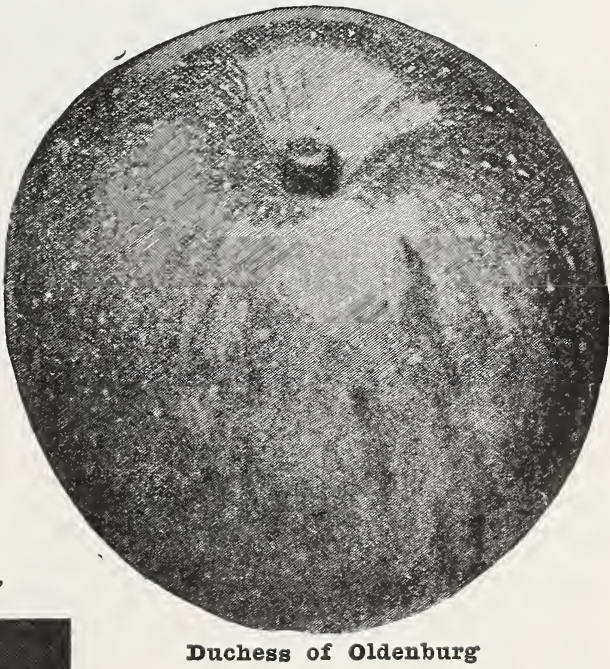

Red Astrachan-Large, roundish; nearly covered with deep crimson; overspread with a thick bloom: juicy; rich; acid. Cooking and eating variety, suitable for market. Tree a vigorous grower with large foliage; a good bearer. August.

Yellow Transparent-Good size: clear white turning to pale yellow; flavor sub-acid highly prized for cooking and eating; popular market variety. Tree of Russian origin; upright grower; bears early and abundantly; hardy. July-August.

\section{Fall Varieties}

Bietigheimer (Red Bietigheimer)-Large to very large; pale green color, mostly covered with purplish-crimson stripes; flesh white firm and rather dry. A good cooking apple which attracts attention in market on account of size. Tree, German origin, a fine grower, abundant bearer. September-October.

Chenango (Strawberry) - Rather large, oblong, conic, angular; whitish-yellow striped and splashed with light crimson: flesh white very tender, with mild, pleasant sub-acid 


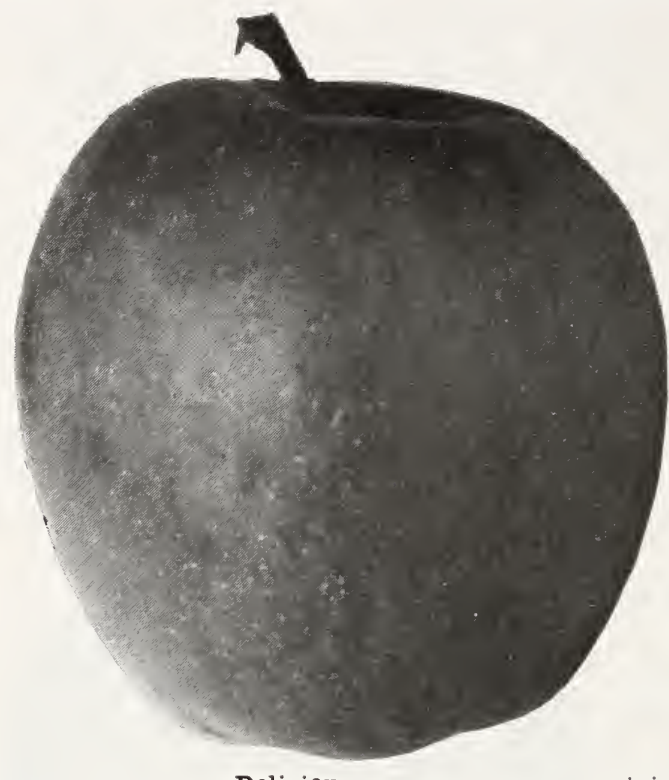

Delicious

flavor. A market and eating variety. Tree vigorous and productive.

Fall Pippin-Very large, roundish, oblong, yellow; flesh tender and delicious. One of the most valuable varieties for table or market. Tree a free grower and a fine bearer. October-December.

* Fameuse (Snow Apple)-Medium size; pale, greenish-yellow, mixed with stripes of red and splashes of red on shady side; flesh white, tender and juicy, slightly perfumed, sub-acid; extra good; recommender for table, kitchen and market. An old and well known variety. Tree a moderate grower but productive. October-November.

Gravenstein-Large, rather flat; yellow, with red stripes; beautiful and showy; flesh firm, tender and crisp. highly flavored; cooking and market. Generally recommended as a good fall variety.

Fubbardston (Nonesuch)-Large, yellow with red stripes; flesh tender and juicy; sub-acid, very good flavor recommended for dessert and market. Very productive. November-January.

Maiden Blush-Medium size, smooth, beautifully flushed with red on creamyyellow; flesh tender, of pleasant but not high flavor. A good market sort because of attractive appearance and all-around utility. Tree a fair grower and produc. tive. September-October.

Rambo-Medium size; oblate; smooth, streaked and marbled with dull yellowish ground; dots large, whitish; flesh tender rich, mild, sub-acid. An old variety; good for cooking or eating. Tree a great grower and very productive. Most popular in the west. October-December.

Twenty Ounce (Cayuga Red Streak) Verv large; striped; very showy; flesh fair quality, pleasant; sub-acid; excellent for baking; popular market kind. Tree good grower and fine bearer. October-January.

wealthy-Medium size; roundish; smooth nearly covered with dark red; very good; dessert; very profitable as a market sort. Tree good grower and productive. October-January.

\section{Winter Varieties}

Arkansas Black-Large, round, smooth; often very black; flesh yellow, juicy and delicious when ripe; cooking or market; splendid keeper. Tree vigorous, hardy and abundant bearer. December-April.

Baldwin-Medium size; conical; bright red; flesh crisp, juicy, subacid; rich flavor; great market variety of eastern states for cooking, dessert and market. Tree vigorous, open head. Abundant crops, but does not bear young. November-March.

Banana-Medium size ; smooth; easily polished; deep yellow; slight blush; flesh solid, juicy; mild subacid; has delicate banana perfume and flavor; very popular for dessert and market.

Delicious-Flourishes well in every state of the union. Bears annually; great yielder; hangs well on trees. Trees very thrifty, long lived and extremely hardy. Fruit very large, nearly covered with brilliant, dark red; flesh fine grained, crisp, juicy, melting and delicious; splendid keeper and shipper; should be in every orchard.

Een Davis-Medium large; red, striped; flesh white; sub-acid; rather coarse grained; great market variety but not really good until very late. Tree very vigorous and productive; rarely fails to crop. December-March.

English Russet-Medium size; very regular; greenish-yellow and nearly covered with russet; flesh yellowish-white, firm and crisp, with pleasant flavor. Recommended for dessert and market. Tree vigorous grower and good bearer, hardy. November to April.

Fallawater (Tulpehocken)-Very large, handsome green, nearly covered with dull red; flesh juicy, crisp, pleasant; sub-aciã. Home use and local market. Tree a strong grower, very productive, even while young. November to March.

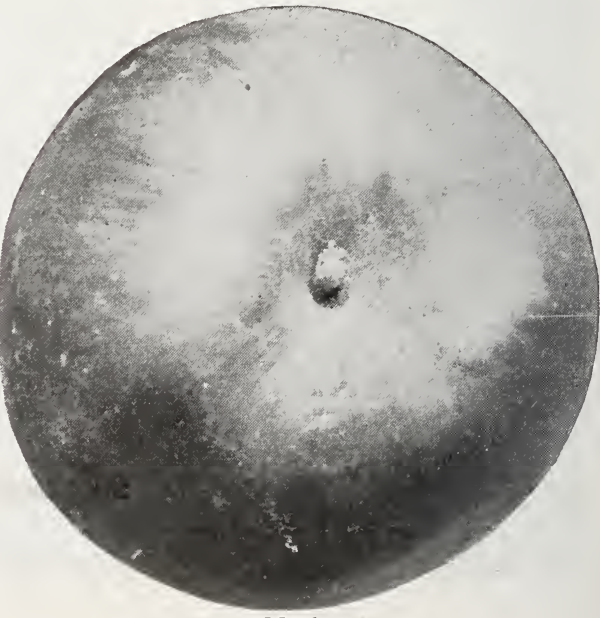

Baldwin 


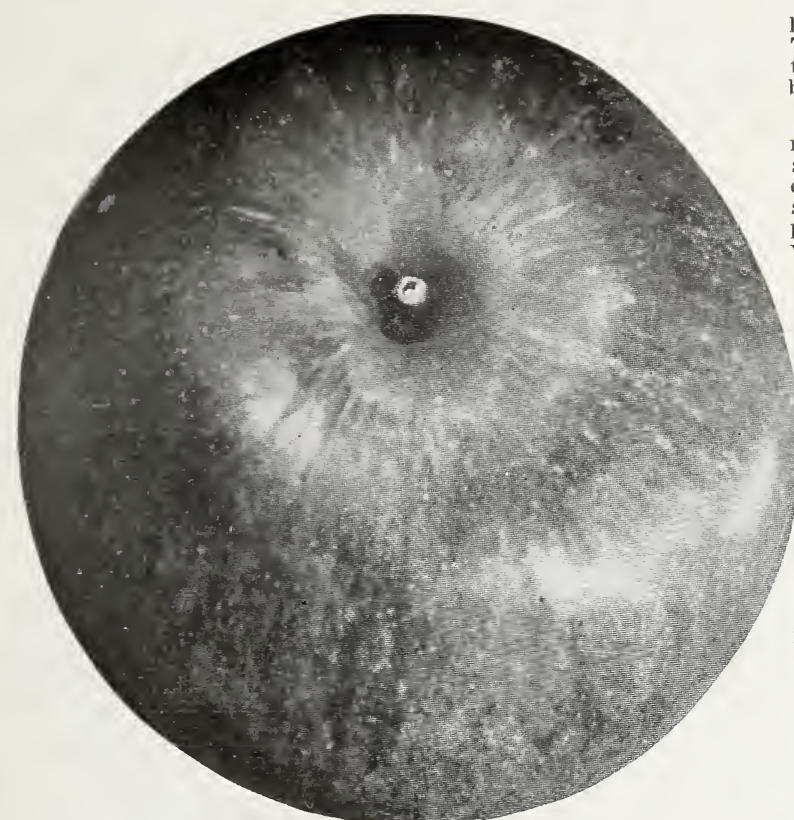

Stayman's Winesap

Gano (Black Ben)-Large; conical; smooth; very deep red and attractive; flesh pale yellow, fine grained; mild sub-acid. A good shipper and keeper for market. Tree healthy, vigorous and hardy; annual bearer. February to May.

Grimes Golden-Medium size; regular; rich, golden yellow; flesh yellow, firm, crisp. aromatic, rich; quality very best. Top-notcher in market. Tree hardy and productive; bears early; blossoms late in spring frost seldom catches them. One of the best sorts. November to January.

Jonathan (New Spitzenberg)-Medium size; roundish; yellow, nearly covered with red; flesh white, fine grained, juicy, tender and mild; a delicious and strictly dessert apple that always demands highest market prices. Seedling of Spitzenberg. Is a much better tree; vigorous and productive. November to April.

McIntosh (MeIntosh Red)-Medium large; polished; smooth; yellow, nearly covered with brilliant crimson; beautiful flesh snow white, crisp, very tender, arom atic; sub-acid; very good quality. Resembles Fameuse type, but is larger and mole hardy. Tree vigorous, with spreading head, a good annual bearer; popular in north west. November to February.

Northern Spy-Large; roundish; slightly conical; striped, with sunny side purplish-red; flesh white and tender, with mild, rich, spicy flavor. An old favorite and one of the best all-around apples grown. Tree is a strong, upright grower, head ver. compact and should be opened up by pruning to admit air and light. December-June.

Northwestern Greening-Large; round; green, turning to yellowish-green when ripe: flesh yellow, fine grained and firm. good flavor, smooth and attractive; mar- ket sort bringing high prices, Tree one of best growers in the west; extremely hardy and bears young. Blossoms early.

Ralls (Janet)-Medium size, roundish; greenish yellow streaked with red; flesh white, crisp, rich and juicy; pleasant sub-acid; recommended for all purposes as excellent. Tree vigorous but slow grower. Comes into blossom late and sometimes escapes frost damage. Long and good keeper.

Rhode Island GreeningLarge; greenish yellow; tender, juicy, rather acid but high flavored; very popular; extra good cooker. An old standard sort. Tree vigorous and spreading; a heavy and constant bearer. December-March.

Rome Beauty - Large; round: mottled and striped in different shades of red; flesh yellowish, tender; juicy; sub-acid; recommended as a dessert and market variety. Good grower, blooms late, productive; especially recommended in eastern states. November-February.

Salome-Medium size, conical; yellow ground, red, striped; flesh whitish-yellow; half fine; tender; mild sub-acid; good; recommended as an all-around apple till summer, does not get dry until July or August. Tree a strong grower, very hardy; bears young, alternating heavy and light crops.

Stayman's winesap-Medium size, roundish; greenish-yellow, red striped; flesh yellow, firm, fine grained, crisp, juicy, aromatic recommended for cooking and eating. Tree quick and vigorous grower, adapts itself readily to different soils and situations. November to February.

Talman Sweet-Medium size; pale yellow; flesh fine grained, white, firm, moderately juicy and very sweet; quality excellent. Tree vigorous, upright, spreadins and very productive; one of the old eastern varieties. December-March.

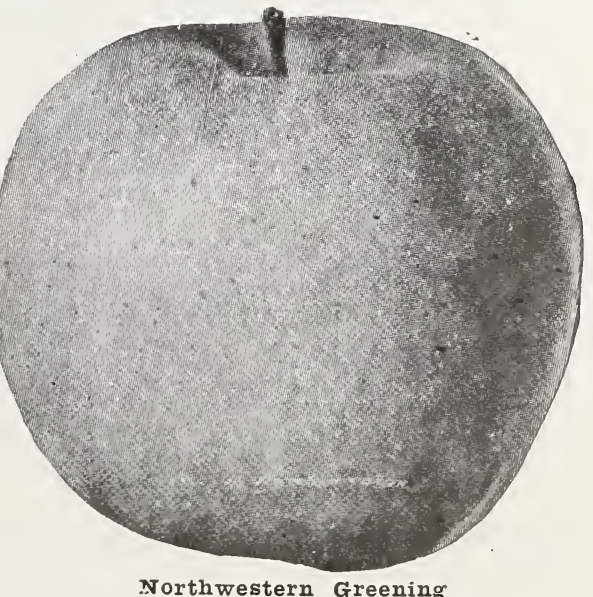


Tompkins King (King Tompkins County) -Very large; attracts attention by size: red; flesh yellowish, crisp and tender, subacid of best quality; always in demand on market. Tree vigorous grower, good bearer and hardy. November-January.

Winesap-Medium size; roundish; deep red; flesh yellow, firm, crisp, juicy; excellent quality; a leading export variety. Tree moderately vigorous with open irregular head; very productive and an early bearer.

Wolf River-Very large; handsome; red on greenish-yellow skin; flesh whitish, tinged with yellow, very firm, tender, juicy and of good quality, rather acid; market sort. Tree very hardy and productive.

Yellow Belleflower-Very large; sometimes angular; pale yellow, often with a blush; flesh white, very tender when ripe, fine grained, crisp and juicy, acid, becoming sub-acid later; an old and highly recom- mended variets. Tree rather upright. November-February.

Yellow Newton (Newton Pippin)-Medium large; round or a little lop-sided and somewhat irregular; yellowish-green; flesh very juicy, crisp and highly delicious flavor; rated as among the very best allaround varieties. Tree needs rich soil, and is a rather slow grower. DecemberMay.

York Imperial-Medium large; often oblong; greenish-yellow, covered with bright red; flesh crisp and juicy when mellow. A great variety for cold storage market and raised in immense quantities in Pennsylvania section. Tree vigorous and productive, almost equalling Ben Davis.

Paradise winter sweet-Large; round; brownish-white to yellow; flesh white, fine grained, juicy, sweet, sprightly; market or home. Tree upright, moderate grower blights in some localities. December to March.

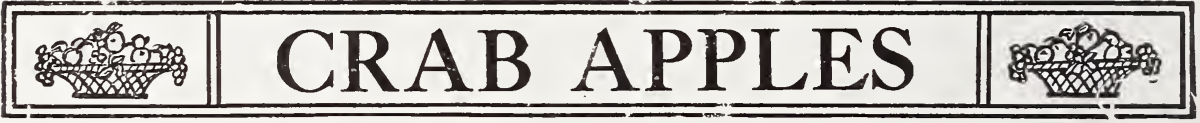

Crab apples are especially desirable in the colder sections as only a few varieties of apples can be successfully grown; but they succeed well in all climates and their fruit is very popular for preserves, jelly and some sorts are excellent for eating.

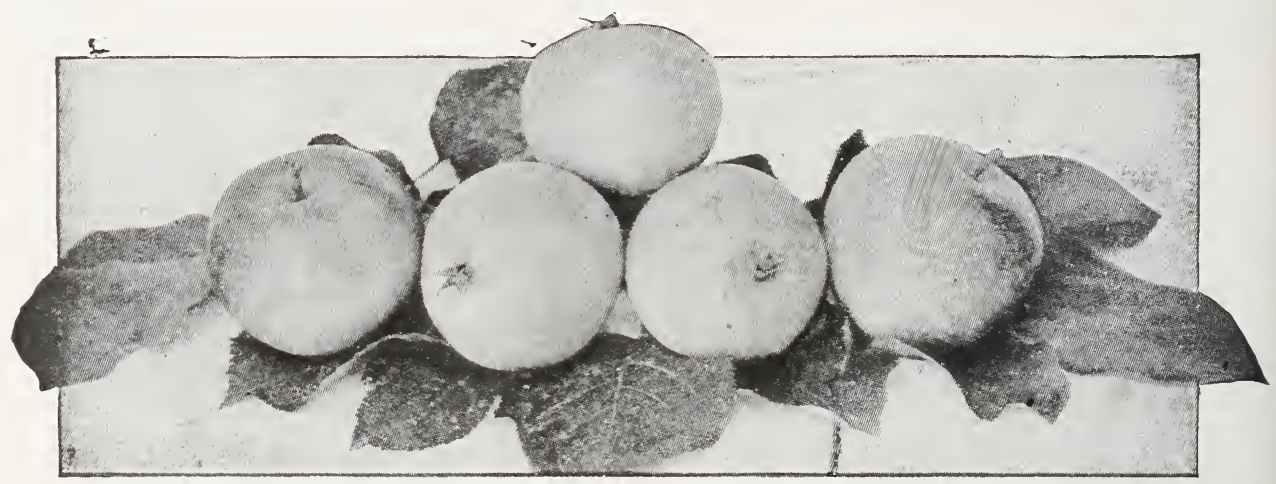

Transcendent

Alaska-Fruit larger than Transcendent; yellow; flavor excellent; long keeper; tree a strong grower and perfectly hardy.

Gideon-Large; waxy white, slightly golden on sunny side. Tree resembles Duchess of Oldenburg, both in habit and growth; very hardy and productive.

Hyslop-Large, round, conical; yellow, with heavy shadings of deep crimson and splashes of maroon with heavy blue bloom; flesh fine, firm, yellow, astringent; its high color always commands a fancy market price. Tree very vigorous where hardy, blights in some localities; bears abundantly in clusters, which make them exceedingly ornamental. September-October.

Sweet Russet-Medium or small; round, oblate: yellow, with scarlet cheek: flesh yellow and acid; recommended for cooking and market. Tree hardy; fruit grows in clusters: bears young and abundant. A fine variety. Ripens August-September.

Transcendent-MFedium large, oblate; golden yellow, with blush; flesh firm, crisp yellowish, fine grained very juicy and acid; when ripe is edible. It is generally grown all over the United States and is very popular for cider as well as jelly and preserves. Tree grows rapid and irregular; a great bearer; subject to blight and should not be planted near other apple trees. September.

Whitney-Large, averaging one and onehalf to two inches: round, conical; smooth, glossy yellow, with red stripes; flesh firm juicy and rich; almost sweet; especially bred for wine and cider. Tree hardy, handsome and very productive. August.

Yellow siberian-Small, round; yellow; flesh yellowish and acid; popular on market for jellies. Tree vigorous and hardy. 


\section{PEARS}

The pear is the most delicious of modern fruits on account of its fine, juicy texture, exquisite flavor and aroma. While some varieties do better if picked when partially ripe and finished in doors, yet the really enjoyable supply should come from the home orchard, planting a number of varieties that will ripen in succession, from fall to winter.

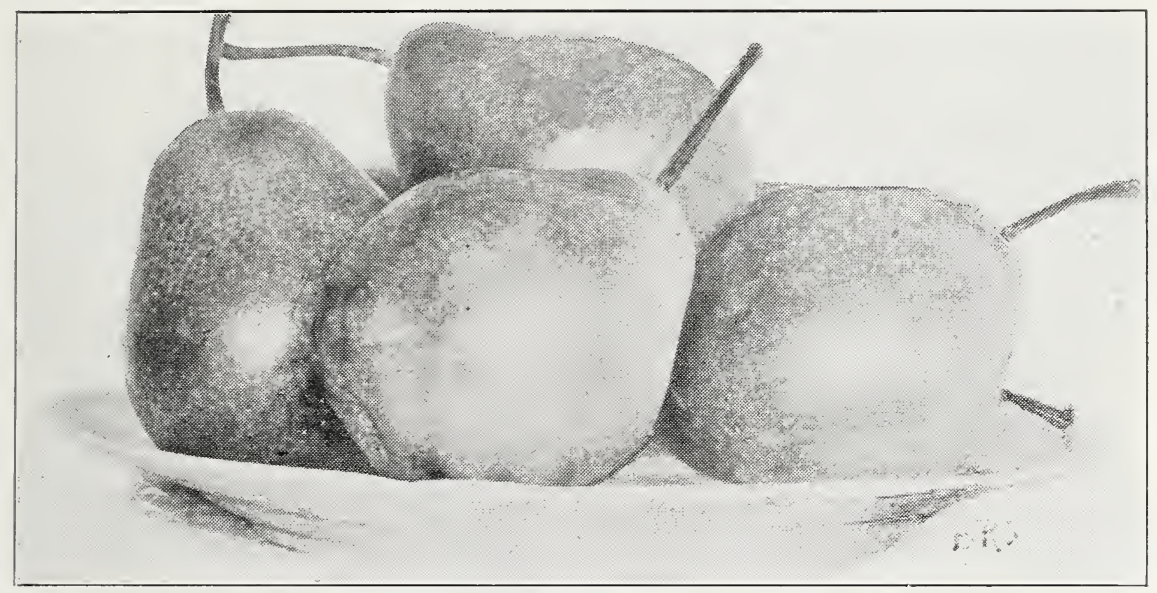

\section{Summer Varieties}

Bartlett-Large; rich yellow, with beautiful blush next the sun; buttery, very juicy and highly flavored. Very popular; grown everywhere. A favorite market variety. Tree a strong grower; bears early and abundantly. Does best as a standard. Last of August and early September.

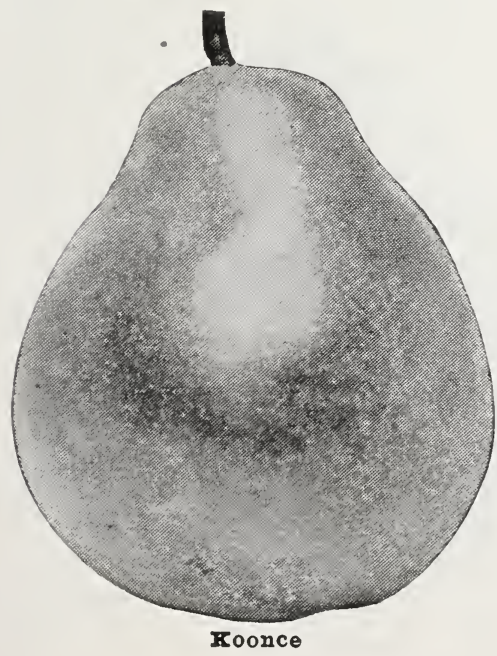

Bartlett

Clapp's Favorite (Fay)-Iarge; pale lemon yellow with red cheek; flesh of fine texture, melting buttery, juicy, with a rich vinous flavor; good for market and kitchen. Tree hardy ana very productive, does well in all sections. Standard or dwarf. August.

Early Harvest-Medium; golden yellow, with red cheek; flavor not the best but recommended for kitchen and market because extremely early -a month before Bartlett.

*Koonce-Medium; yellow, with red cheek, orisinated in southern Illinois; largely planted for market sort. Can be picked green and will color up well in a few days. Tree vigorous, bearing large crops annually. July-August.

*Seckel-Medium: vellow, with crimson cheek; flesh melting, sweet and aromatic; most exquisitely flavored pear known. Tree slow grower, but hardy and healthy. September.

summer Doyenne (Doy de Ette)-Small; yel. lowish: melting, sweet; very good quality for dessert. Tree vigorous and productive. August.

Tyson-Medium small; bright yellow with russet cheek; flesh melting, sweet and delicious. Tree upright, hardy, but not so early to bear; recommended for the west. August. Standard or dwarf.

*wilder-Medium small; yellow, with dark red cheek; flesh melting, sweet and good for dessert; popular on market. Tree very attractive, of vigorous and symmetrical growth. Standard or dwarf. Early August.

\section{Autumn Varieties}

Anjou (Buerre D'Anjou)-Large; greenish, shaded with russet-crimson; flesh is highly flavored, vinous and rich; dessert and market sort; 


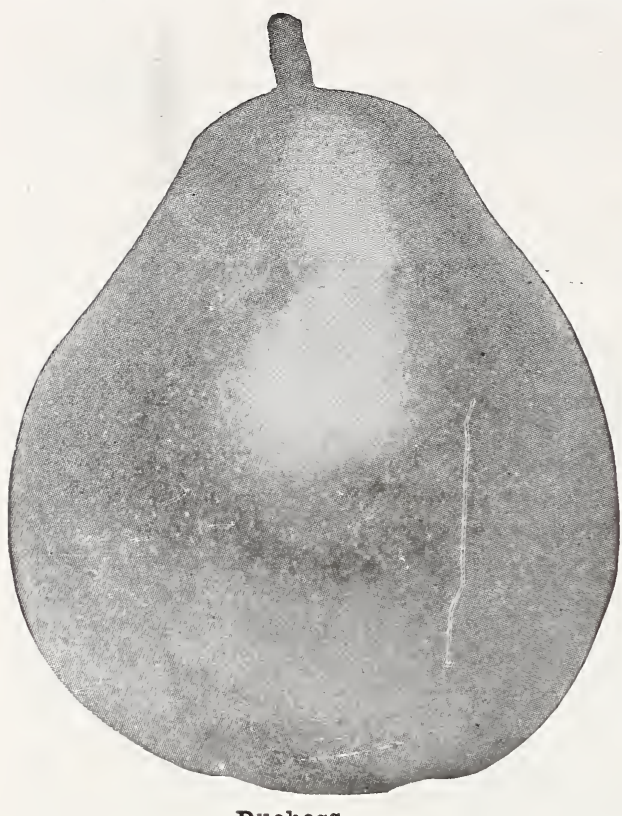

Duchess

keeps well until winter holidays, when it commands a high price. Tree hardy and productive and succeeds well in all sections. October-January.

Clairgeau (Beurre Clairgeau) - Large; yellow, with russet and brown, sometimes shaded with crimson, flesh yellow, juicy, recommended for cooking and market sort. Tree a very good grower and bears early. Standard or Dwarf. October-November.

*Duchesg (Douchesse d'Angoleme)-Very large; green and yellow, with russet; flesh very juicy, with rich, excellent flavor. An all around variety for dessert, cooking and market. Succeeds best as a dwarf.
Flemish (Flemish Beauty)-Large; pale yellow, covered with light russet, turning reddish-brown when ripe, flesh juicy, very sweet, rich and melting; recommended for extreme northern states. Standard and dwarf. September.

Garber-Large; bright yellow, with red blush; flesh juicy and rich; a cross with the Kieffer but two weeks earlier and better quality. Tree very productive and bears three years after planting. Standărd. September.

Idaho-Large, nearly globular; rich light yellow, covered with small "freckles"; flesh white, grained and rich; generally considered a good market sort but little grown for home use.

Kieffer-Medium large; yellow and crimson, with russet and brown; flesh firm and good when ripe; the Ben Davis of the pear family; when properly ripened is delicious, Tree vigorous, with healthy, dark green foliage; an early bearer and very productive everywhere. October.

Worden (Worden's Seckel)-Medium size; golden yellow, with russet cheek; flesh fine grained, juicy, buttery, with a rich aroma; recommended highly as a dessert and market sort. Tree hardy and an enormous bearer. September.

\section{Winter Varieties}

Drouard (President)-Very large; greenish-yellow and russet; very handsome; flesh melting, juicy and highly aromatic; recommended for dessert and market. Tree vigorous, healthy and prolific bearer. February-March.

Iincoln Coreless-Large; golden yellow; quality only medium, distinctive as having very few if any seeds, almost clear of core. Tree good grower and productive, reported to blight in some localities.

winter Nelis-Medium; greenish-yellow, with russet; flesh fine grained, melting and rich; considered one of the most delicious and best winter sorts. Tree straggly and slender grower, but hardy and thrifty. Standard or dwarf.

\section{QUINCES}

Angers-Medium size, pear shaped; golden yellow; rather acid, tree a thrifty grower and abundant bearer. October.

Champion-Very large, greenish-yellow, flesh cooks as tender as an apple and without hard spots or cores; flavor delicate, imparting an exquisite quince taste and odor to any fruit with which it is cooked. Trees are vigorous growers and bear heavy crops of superior fruit; one of the best for sections not subject to early frosts.

Meech's Frolific-Large size, bright yellow, very fragrant, good flavor; one of the best; bears early and very productive.

Orange-Large, bright golden yellow; fine, firm flesh and good flavor; one of the best for cooking. The most popular and extensively cultivated of the old varieties. October.

All our fruit trees, shrubs and vines are guaranteed to be true to name and if a mistake should be made will be glad to rectify.

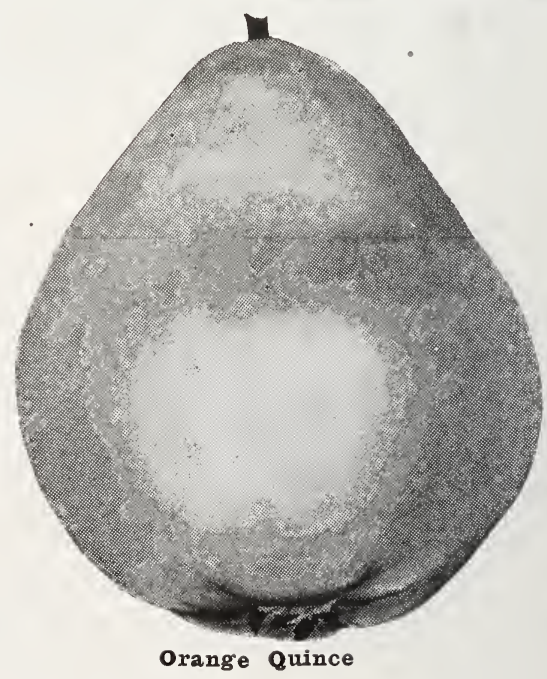




\section{PEACHES}

Every home should have a few peach trees as there is no more delicious fruit in its season, and that purchased on the market is often of an inferior quality because of the necessities of picking comparatively green. Peach trees grow quickly but are of short life and to keep a good supply of fruit, a few trees should be set out each year to replace those that die of old age or accident.

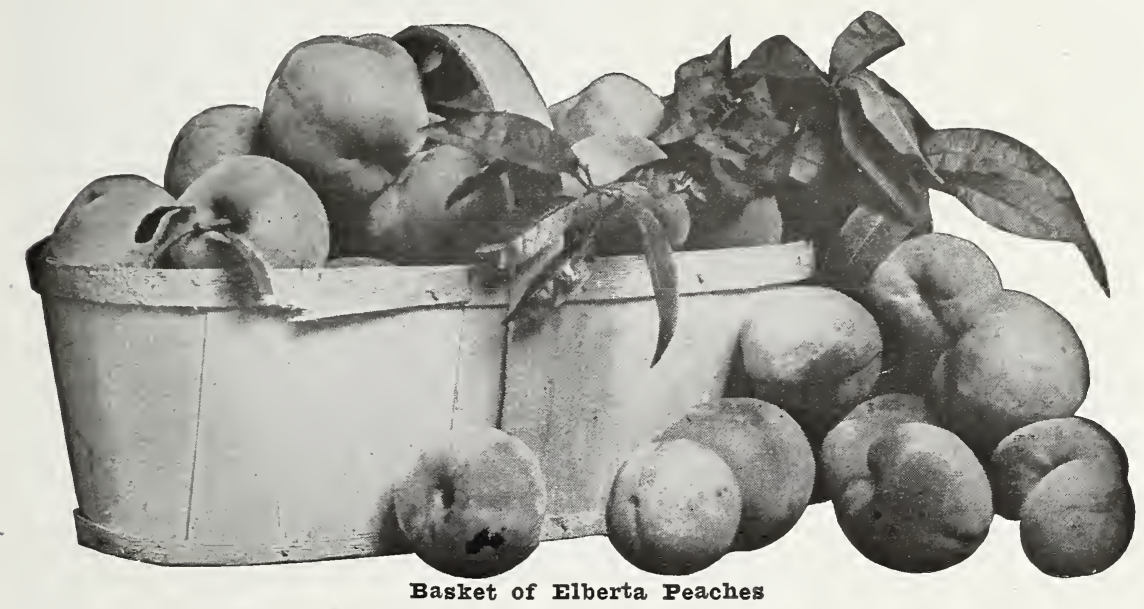

Alexander (Semi-Cling)-Medium; greenish-white with red blush; flesh sweet and juicy. A good market sort. Tree vigorous and very productive.

Banner-Large, round; yellow, with crimson cheek; flesh firm, yellow, rich, excellent; keeps and ships as well as any peach on the market; general utility and recommended as among the very best. Tree early bearing, productive and hardy. Originated in Canada. October.

Beers Smock-Medium large; creamy white, with crimson blush; flesh yellow, tender and rich; very good quality for the season and recommended for market. Tree a rapid grower, prolific bearer and hardy. Late September-October.

Belle of Georgia-Medium large, oblate; white, with red cheek; flesh white, firm and excellent flavor; recommended for dessert, kitchen and market. Tree a rapid grower and very productive. Early July.

Carman-Large, round; white, with deep blush; flesh tender and juicy, with fine flavor; skin very tough, making it available for marketing with profit. Tree reported very hardy and a prolific bearer. August.

Champion-Large, round, quite regular creamy yellow, with red blusin; flesh white with red stains around pit; flavor delicious, sweet and juicy. Tree very hardy and productive. First of September.

Crawford's Late-Large; yellow or greenish-rellow, with dull red cheek; flesh yellow, stained red at pit, melting, vinous and very good. Tree hardy and productive, usually needs thinning to make good sized fruit. Last of September.
Crawford's Early-Large; yellow, with red cheek; flesh yellow, juicy sweet; its size and beauty make it very popular. Tree vigorous and productive, but buds are very tender. First of September.

Dewey (Admiral Dewey)-Medium size; yellow; flesh firm, yellow and delicious good shipper; highly recommended as a very early sort. Tree is strong, hardy, symmetrical grower and produces well. July.

Ede (Captain Ede)-Very large; yellow, tinted with red; flesh yellow and about same quality as Elberta: claimed to be hardier than Elberta and as good a market sort. August-September.

Elberta-Very large; red blush; flesh yellow with pale yellow, tender and juicy; the great market peach of the country. Rank, vigorous grower, does well in all peach growing sections. Middle September.

Hale-Very large; yellow with profuse blush, thin skin with little fuzz; flesh yellow, solid and better than Elberta, which it supplements. Tree good grower and heavy producer. Ripens a week before Elberta.

Kalamazoo-Medium to large; oval; yellow, striped with red and a thin bloom; flesh yellow, red at pit; rich, vinous and of good quality. Tree a strong grower and bears at two years old; hardy and reliable. September.

Iemon Free-Medium, large, roundish; often with pointed apex; light yellow, with greenish-white tinge and thick bloom; flesh yellow, tender and good; a good can- 
ning sort. Tree a regular and prolific bearer. October.

Mayflower-Medium size; practically red all over; flesh firm and of good flavor; extremely valuable as a very early market sort, especially in southern states. Tree blooms very late; upright and good grower; prolific bearer. Earliest known.

smock-Large, roundish, soemwhat oval; yellow, with some blush and thick bloom; flesh yellow, tender and sprightly. A good market sort.

Steven's Rareripe-Medium, oblong; creamy white, with beautiful blush; flesh white and of highest quality. Tree bears early and is prolific. Early October.

Stump_-Very large, roundish: white, with a red cheek, considerable bloom; flesh white, juicy and good flavor. Tree very prolific. Last of September.

Triumph-Medium large; dark vellow, nearly covered with red; flesh yellow nearly to pit, where it changes to greenish-white; juicy, melting and sub-acid; an attractive market sort. July.

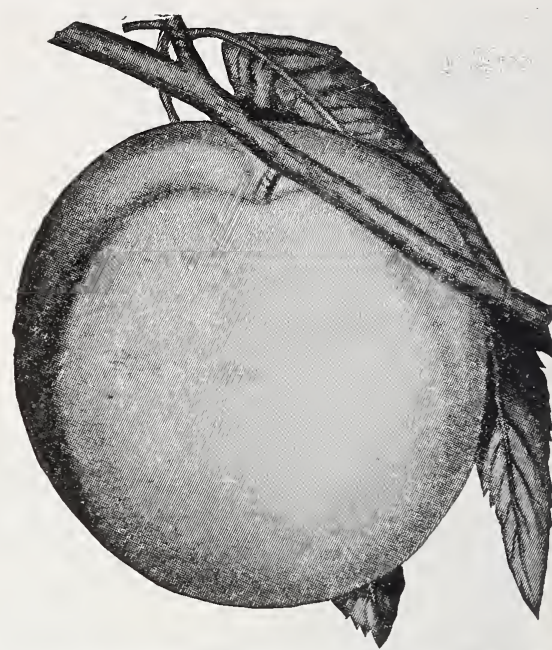

The plum, like a pear, succeeds best in a rather heavy soil with some clay and being generally. free from disease is profitable. They should be gathered a few days ahead of use that they may develop their perfect flavor. For family use they especially do well in poultry yards, or where the hogs keep the ground free of fallen fruit. The varieties should be mixed.

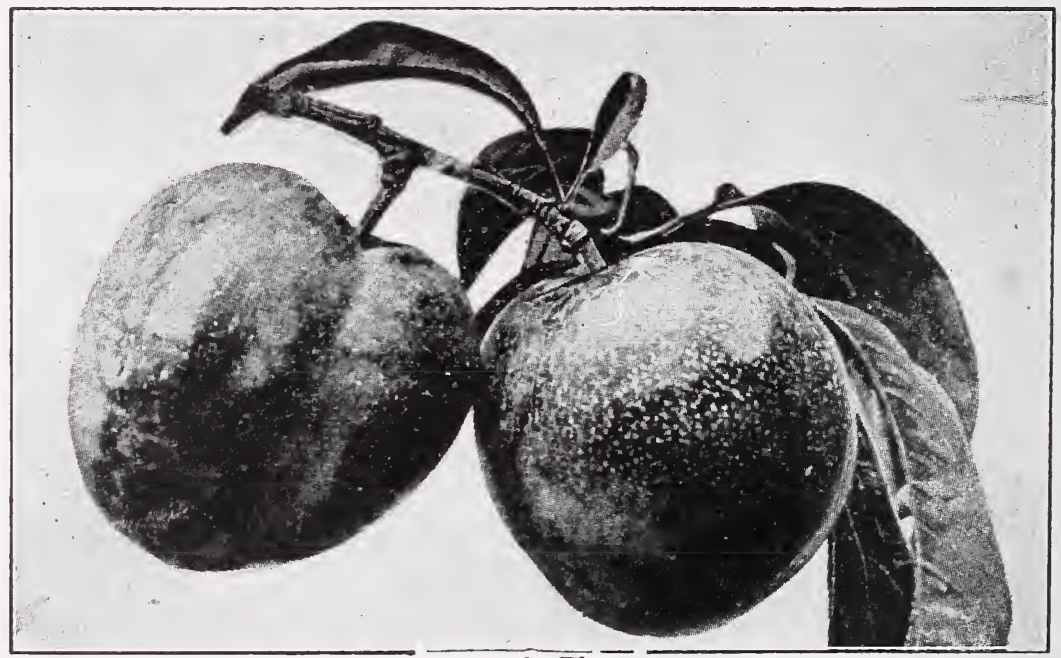

Burbank PIum.

\section{American Varieties}

DeSota (Wis.)-Medium; yellow with red cheek and thin blue bloom; cling; flesh firm, juicy and highly flavored; kitchen and market sort. Tree is very hardy and healthy; its fault is over-bearing and should be thinned. Last of August.

Forest Garden (Iowa)-Large; dull pur- plish-red; cling; flesh yellow or reddish near stone, firm, sweet and pleasant flavor; one of the very best sorts for kitchen. Tree thrifty upright grower; regular bearer. Medium early.

Stoddard (Iowa)-Large; yellow, with red cheek; cling; flesh splendid for dessert, develops too much acid for cooking. August. 


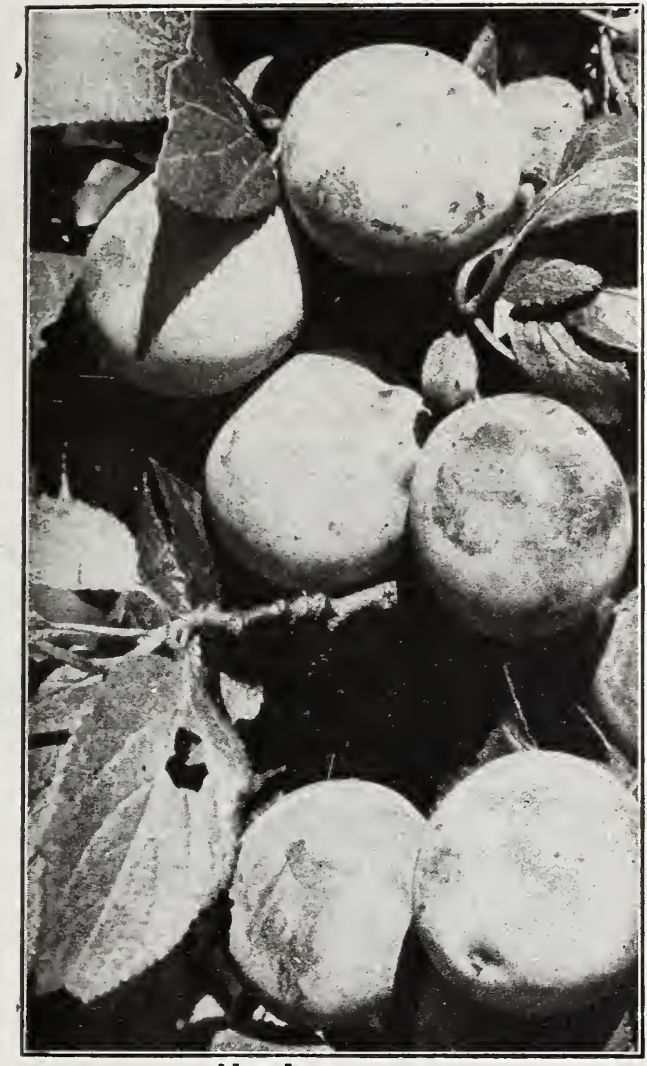

Abundance

wild Goose (Tenn.)-Medium to large; red with purplish bloom; cling; flesh yellow, juicy and sweet, recommended for kitchen and market. Tree vigorous and good bearer. July.

\section{Domestic Varieties}

Arctic (Maine)-Medium small; very dark purple: blue bloom; semi-cling; flesh greenish-yellow, juicy and sweet, with pleasant flavor; for dessert and market Tree healthy and vigorous; early and abundant bearer.

Bradshaw (Niagara, Amer)-Medium large; purplish-red; free; flesh green and juicy; good shipping qualities. Tree an upright grower, bears regularly; enormous crops. Medium early.

Damson (Europe)-Small; black, with thick blue bloom; free; flesh juicy, but lather tart: best for kitchen and market. Tree enormolisly productive and hardy. September.

Imperial Gage (N. Y.)-Medium; yellowish-green; heavy white bloom; free; flesh juicy, sweet, rich and excellent: one of the very best dessert and market. Tree upright and vigorous. September.

Italian Prune (Europe)-Medium large: purplish-black; blue bloom; free; flesh greenish-yellow, juicy, sweet and of good quality; will hang on tree after ripening;

splendid for drying and market. Tree very productive. September.

Iombard (N. Y.)-Medium large; reddish-violet, with heavy bloom; cling; flesh firm, yellow and very pleasant for both kitchen and market. Tree unusually vigorous, succeeding well on even light soils. Late August.

Monarch (Eng.)-Large; reddish to blue-purple; thin bloom; free; flesh pale golden-green, juicy, pleasant; recommended for dessert, kitchen and market. Trees come into bearing young and yield abundantly. August.

Yellow Egg (Europe)-Very large; greenish-yellow; flesh a little coarse but recommended for drying and cooking. Tree a free grower and very productive. Late August.

\section{Hybrid Varieties}

Abundance (Japan)-Medium to large; a rich cherry red; with a decided white bloom: cling; flesh light yellow, exceedingly juicy, tender and delicious; kitchen and market. Tree vigorous and hardy; rapid grower and bears young. Last of July.

Burbank (Japan)-Large; reddishpurple; cling; flesh yellow; juicy; sood for kitchen and market. Tree rather spreading and abundant bearer; very hardy and prolific. NFedium late.

Climax-Large; heart shaped; deep rich red; flesh sweet and fine; tree strong, thrifty and very productive. One of earliest to ripen.

Compass Cherry-Small; purplish red, with large pit, flesh yellow and very good for cooking. The original cross of Minor Plum and sand Cherry.

Fanska-Beautiful color, bright red, with heavy bloom; flesh firm, yellow and good quality; fragrant; apricot flavor; tree tall, rapid grower; pit small.

Red June (Japan)-Medium; vermillion red with bloom; semi-cling; flesh light lemon yellow; slightly sub-acid; but good quality for kitchen and market. Tree strong and spreading; unusually productive. Early.

wickson (Calif.)-Very large; reddishpurple, with white bloom; cling; flesh firm and meaty; yellow, rich, aromatic; a market sort. Tree strong and spreading; bears abundantly and early in most localities. August.

Toka_Similar to tre Hanska, of same parentage: tree remarkably strong and vigorous grower, making model tree; early and heavy bearer of handsome fruit.

Opata - Flesh firm, greenish with pleasant flavor. Pit small; season early; is strong grower and heavy bearer.

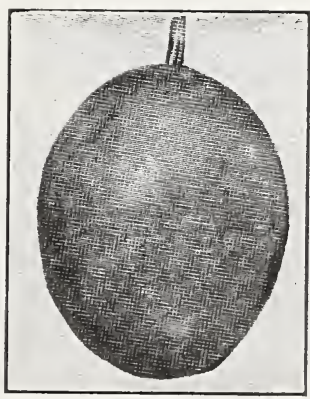

Italian Prune 


\section{CHERRIES}

While the cherry tree is of rather slow growth it is so sturdy and hearty and bears for so many years a large, bountiful crop under the most adverse conditions, that a few of them are the most valuable tree that a home man can plant. Where room is available a few of the sweet varieties is very desirable, but owing to their uncertain cropping, some of the sour varieties should also be included among the selections.

Cherry trees are now generally propagated by budding on Mahaleb stocks, since they do not sprout from the roots. They should be planted deep enough to place the point of union from four to six inches below the surface.

Saylor sweet Cherry-This is the first time that we have been able to offer a hardy, sweet Cherry to our Iowa planters We have been testing, in the last twentyfive years, a dozen varieties, but have a last found one strictly hardy, high grade, and very productive. The history of the Cherry is that it is a stray that was in. troduced by the Iowa Agricultural College in 1880 . We are not certain as to its origin, but as to its hardiness will say that it is equal to any Cherry that we have Its color would be called white or yellow, fruit very large and sweet, with just a little, mild sub-acid. Tree is a great bearer, leaves large and very thick. We have named the Cherry the Saylor, for the reason that Professor Chas. Saylor, of Des Moines, Iowa, has growing on his lot three of these Cherries which are now fifteen years old. They have given him eight heavy crops right along. We are confident that the fruit planting public will hail the good news of a hardy sweet Cherry and we hope to have our friends try them. and we are confident they will prove hardy anywhere that the Early Richmond or Montmorency will grow.

Spanish-Large, pale yellow with red cheek; flesh firm and juicy. One of the best light colored cherries for dessert. Tree very productive. June.

Tartarian (Black Tartarian)- Very large; purplish-black, heart-shaped; flesh mild and sweet and quality considered the very best for market and dessert. Tree is a vigorous, upright grower and immense bearer. July.

Windsor-Large, dull red; flesh very firm, and fine quality; good bearel. No cherry in recent years has attracted more attention. Has been recommended by some of the most prominent fruit growers of the country.

wood (Governor Wood)-Large, round, heart-shaped; yellow, mottled with red; flesh sweet, juicy and delicious. Tree healthy, vigorous and a great bearer. Fruit hangs well on tree. June.

\section{SOUR VARIETIES}

Compass-Originated in Minnesota. Is a cross between the Morello cherry and Miner plum. Remarkably hardy and planted extensively in Minnesota and the Dakotas, where encouraging reports have been made as to hardiness and fruitfulness. Its early bearing is wonderful. One year old trees in the nursery now being covered with bloom. Many trees fruit same year they are planted. Unsurpassed in extremely cold climates for canning.

Dyehouse_Medium size; red; flesh melting, juicy with a sprightly tart flavor. Ex-

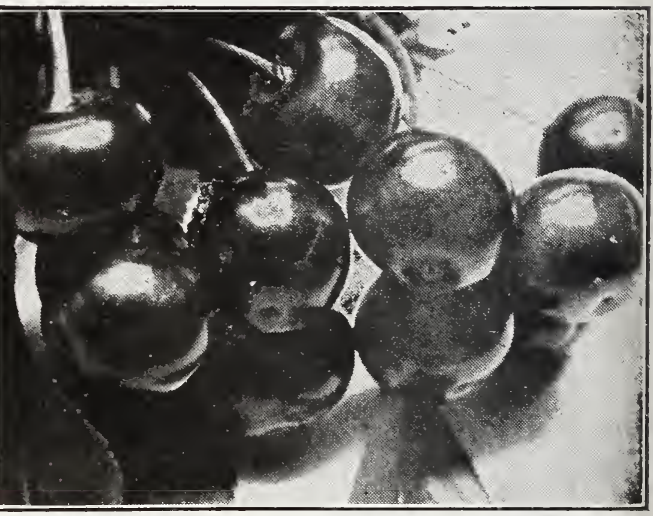

wragg

cellent for canning. Resembles New Rich. mond. Tree hardy and upright.

English Morello-Tree moderate grower hardy; an early and great bearel; the most valuable of the late varieties. Fruit large, round; skin dark red, becoming nearly hlack when fully ripe; flesh dark red, tender, juicy and of a pleasant sub-acid flavor when fully ripe. July.

Iarge Montmorency - A fine, large, light red cherry of the Richmond class, but larger and more solid; a more upright grower, equally hardy and productive. Second only to the Early Richmond in value Ripens ten days later.

Ostheim-Tree medium size, with round, compact top like English Morello; bears early and abundantly. Fruit medium size; almost black when fully ripe; juicy, rich, almost sweet. For eating from the hand it is at the head of our list of hardy cherries. Season late.

Richmond, Early-Medium size, dark red; sprightly acid flavor. This is one of the most valuable and popular of the acid chelries, and is unsurpassed for cooking purposes. Tree a slender grower and is exceedingly productive. The most hardy of all varieties. Ripens through June.

Wragg-Of the English Morello type and very similar in fruit, but averages larger, a few days later in ripening, and possibly has slightly more acidity. Tree dwarfish, with spreading, round head; abundant and regular bearer; bears younger than English Morello, stronger grower; not so subject to disease. During the last twenty years has fruited finely for us. Early August. 


\section{Apricots}

Alexander (Russian)-Medium to small size; light orange flecked with red; flesh tender juicy, sweet, and good flavor; dessert and market. Tree hardy and productive. July.

Early Golden-Small roundish-oval; pale orange with smooth skin; flesh yellow, juicy, sweet and desirable for dessert use. Tree hardy and productive.

Moor Park-Very large; orange-yellow with numerous specks and dots; flesh yellow, sweet, juicy and rich; good to very good market and dessert. Tree is rather tender and fruit ripens unevenly. August.

\section{Mulberries}

Downing-Highly ornamental for street or lawn, bearing an abundance of large, black, sub-acid fruit. Its long bearing season makes it a universal favorite wherever grown.

New American-Equal to Downing in all respects and a much hardier tree. It bears fruits of the finest size and flavor from mid-July until Autumn.

White-A beautiful, ornamental tree and used for its decorative effect. Valuable for feeding silkworms.

\section{Persimmons}

Persimmons (Diospyros)-A native variety with round top and spreading; follage dark green and very dense; fruit over an inch in diameter, pale orange yellow, with a whitish bloom; a beautiful lawn tree.

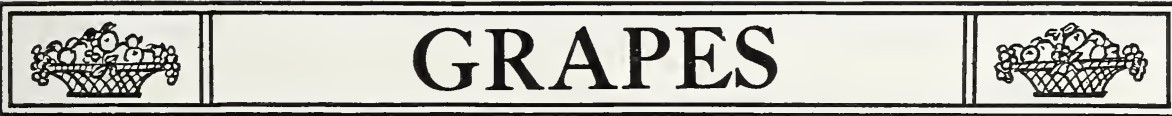

Grapes are one of the most productive and hardy fruits that we have. They can be grown in small spaces and trained up the sides of buildings or along fences, occupying very little room. Make the soil mellow and plant vines somewhat deeper than they stood in the nursery and about 8 feet apart by a fence or building. As a commercial crop they are as desirable as corn and as staple on the market. When a vineyard is once established it will be vei'y productive for a lifetime with ordinary care. Poor soil should be given a liberal application of rotten manure.

\begin{abstract}
Agawam - L a r g e round, early, dark red or brown; 1 a rge, bunched berries, meaty and free from sour pulp; has tough skin and bees never attack it; in flavor it is sprightly, moderately sweet. Midseason.

Beta-A small desirable grape that will prosper as far north as North Dakota, often making a growth of 15 or 20 feet in a single season.
\end{abstract}

Brighton-Medium in size, red; flesh rich, sweet and of the best quality. Ripens earlier than Delaware. Vinous, vigorous and very hardy. Early.

Campbell (Campbell's Early)-Large size, glossy black color, pulp sweet and juicy, seeds small, few in number and part readily from the pulp, clusters very large; an excellent keeper and shipper. Early.

Champion - Large, black grape, medium quality; the earliest of all; strong grower and very hardy; succeeds in all sections, and thus makes it one of the most popular market grapes. Midseason.

Concord-Large, purplish black grape, very hardy and productive, ripening about

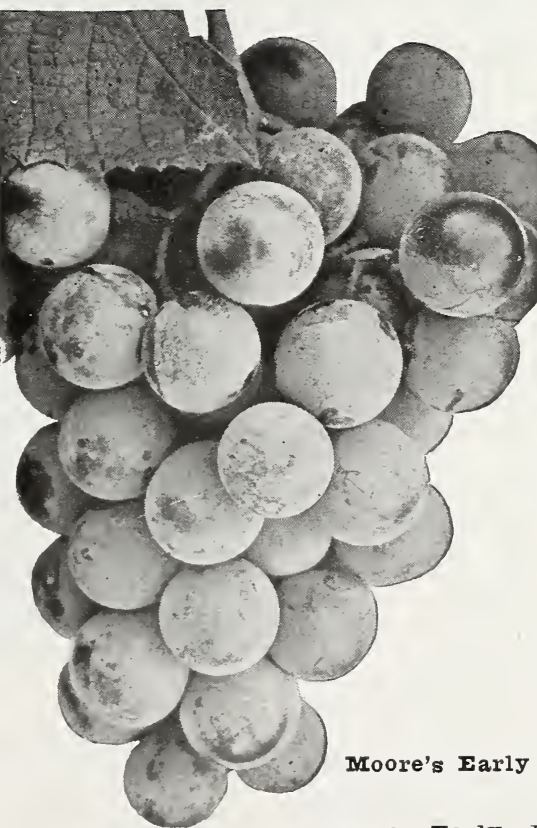

middle of September. This is one of the most popular market grapes.

Catawba - Berries large and round, reddish-coppery colored; flesh fine flavored, sweet. An excellent late sort. Tell known as the great wine grape. Very late.

Delaware - Berries rather small, round, skin thin, light red, flesh juicy without any hard pulp; sweet and spicy and delicious flavor. Vine moderately vigorous, hardy and productive. Ifidseason.

Diamond (Moore's Diamond) - Large delicate, greenishwhite with a yellowish tinge when fully ripe; few seeds, almost free from pulp, excellent quality. Vine like Concord in growth and hardiness and foliage; the leading early white grapes.

Moore's Early-Tery large round; a black with a blue bloom; quality very fine and is classed as better and sweeter than Concord. Extremely hardy and productive.

Niagara-Large, slightly oval; pale yellow with a white bloom; the quality is 
equal to Concord and is the standard white grape of the country. Bunches are large and compact. Vine vigorous, hardy and very productive.

Pocklington-Very large, round, golden yellow; clear, juicy, sweet and tender, with a little pulp; especially a market sort. Vine hardy and healthy, and productive in favorable seasons. Midseason.

vergennes-Large, oval; red or amber; flesh firm, sweet, juicy and of the best quality for dessert and market. Vine hardy, is desirable and quite prolific. Midseason.

worden-Large, rouna; black; flesh has a flavor unlike any other grape; delicious and melting; a dessert and market sort, considered superior to Concord in every way. Vine hardy and productive. Early midseason.

woodruff-Large, round; red; handsome; quality very good and recommended for both dessert and market. Vine a strong grower, healthy and hardy. Early midseason.

\section{NASPBERRIES || RA}

Raspberries are one of the most delicious and popular fruits grown, are easily cultivated and require little care. Cut out old and weak roots each year. Plant in good soil in hills about 4 feet apart. With a little care and attention they will produce large crops of berries. In large plantings it is advisable to plant them thickly the same as hedge row.

\section{Black Varieties}

Conrath-Large; black and very sweet; firm; may be gathered without crushing or breaking; for dessert and market. Bush very vigorous and large grower; needs extra room; very productive. Early.

Cumberland-The largest of all the black-caps; coal black berries; very firm and quality of the very best; excellent shipper. Bush a strong grower, stocky canes and unusually prolific. Midseason.

Eureka-Large; jet black; good quality, firm and ships well for market. Bush good, strong, thrifty grower and hardy. Very early.

Gregg-Large; black, covered with a bloom; quality excellent for shipping, evaporating and general use. Bush hardy and favorably known in very district; productive. Midseason.

Plum Farmer-Large sweet and juicy, but firm; very attractive and recommended for all purposes. Matures fruit in short time.

Kansas-Very large; black; a berry of splendid quality for general use and popular on the market. In many sections it is the leading sort for extensive planting on account of its vigorous and healthy growth, and prolific bearing. Midseason.

Palmer-Large; jet black; sweet and excellent flavor; desirable for dessert and market. Bush hardy, vigorous and productive. One of the very best early sorts.

\section{Red Varieties}

Columbian-Very large; deep purplishred; sweet and highly flavored; for kitchen and market. Bush very vigorous and large grower; needs extra room as it is very productive. Early.

Cuthbert-Very large; conical; rich crimson; very handsome and firm; flavor sweet, rich and luscious; a great market sort and will stand shipping long distances. Bush hardy, both north and south stocky, upright grower and productive. Midseason.

Eaton-Very large; rich red; flesh firm and of excellent texture for shipping. Sprightly and exquisite flavor. Strong sturdy grower and very productive.

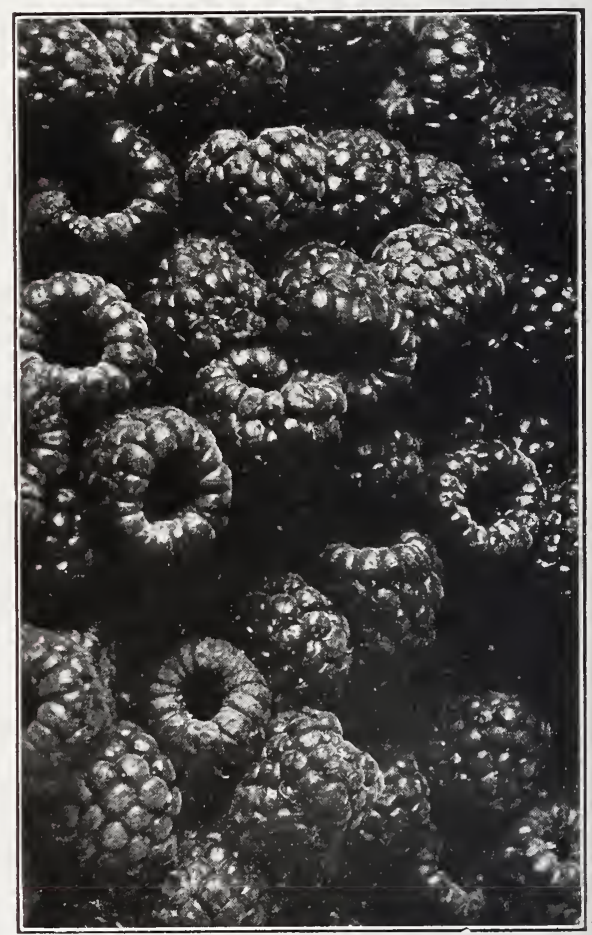

Cuthbert

Golden Queen-Medium large; clear amber yellow with highest quality; for dessert and kitchen; one of the best yellow berries ever introduced. Bush vigorous, hardy, upright and productive.

Ferbert-Originated in Canada. Stands severe winters. Fruit large, bright crimson; unsurpassing quality; rich sugary, of true raspberry flavor. One of the best market berries.

Haymaker-Very large; a bright pur- 
plish-red; excellent flavor; delicious for table use and splendid for canning and shipping. Bush vigorous, hardy and free from diseases and a great producer. Recommended as profitable.

King-Large; crimson; firm; good flavor and desirable for dessert and market; stands shipping excellently. Bush hardy and very productive. Early.

St. Regis-Raspberries for four months.
The new everbearing variety. It gives a crop of fruit all summer and autumn fruiting on the old canes in generous quantities until late in August. By this date berries begin to ripen on the young canes and continue until late in autumn. Berries are a bright crimson of large size and of surpassing quality, rich, sugary with full raspberry flavor. It succeds upon all soils, whether light and sandy or cold heavy clay and the canes are absolutely hardy.

\section{BLACKBERRIES}

We grow our blackberry plants from root-cuttings, and in this way get plants with plenty of fibrous roots, which make sure the growing of the plant. In fruiting patches of blackberries there will spring up many plants from the root, and these are the plants that are usually dug up and sent out to the trade. They have but few, if any, fibrous roots, and are much more apt to die when planted, and will not make the growth after planting that the plants will when grown from root-cuttings.

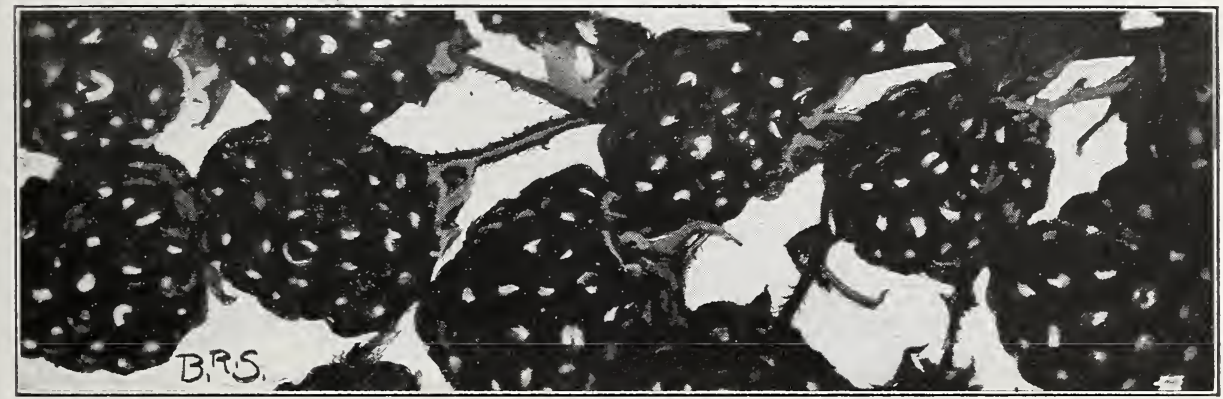

Ancient Briton-Medium size; flesh sweet and melting. Well adapted to market purposes. Canes strong and noted for hardiness in all sections.

Blower-Claimed to be the hardiest,.most productive, the finest quality and for market to bring the highest price of all blackberries. Large size, jet black, good shipper, best quality and unexcelled productiveness are the main characteristics of this splendid new sort.

Early Harvest-Good quality; firm; extremely productive; attractive on the market; an early sort.

Eldorado-Large; black and do not turn red on exposure to sun; sweet and melting, having no hard cores, and good keeper. Vines hardy and vigorous.

Kenoyer-Glossy black; easily picked; never sunburns, and does not turn to red after picking; superior to Early Harvest.

Lawton-Tery large; irregular; roundish, oval; black; very juicy; soft; moderately sweet, finely flavored when ripe. A vigorous grower and exceedingly" productive. Half hardy.

Logan-The Logan berry is a hybrid between the raspberry and blackberry. Fruit as large as the largest blackberry and is produced in immense clusters; the color is clear, dark red. It partakes of the flavor of both the blackberry and the raspberry; very delicious; seeds small, soft and few. Ripens early, just after strawberries.

Mersereau-Large, jet black; extra quality, very sweet; without core; unsurpassed as a shipper and keeper. Remarkably strong grower, claimed to be the hardiest blackberry.

Rathbun-Berries very large; sweet, luscious; have no core and are firm enough to ship and handle well; canes make a strong, erect growth, yielding fine crops.

snyder-Medium size, sweet, melting; extremely hardy and wonderfully productive. Early.

Stone-Medium size, juicy, sweet, fine flavor, good quality. This variety should receive cultivation and be thoroughly prun. ed; it sets more fruit than it can mature properly under ordinary cultivation; particularly adapted to northern Minnesota and sirnilar latitudes.

Ward-Fine, large fruit, without core; black throughout; excellent quality; a healthy and strong grower; resembles the Kittatinny.

Wilson-A very superior, large, early berry, of sweet, excellent quality; strong growing, very productive and is earlier than any other variety. 


\section{DEWBERRIES}

A variety of blackberry that trails on the ground. A very fine fruit both in size and quality. When growing the vines run on the ground, but are tied to stakes for fruiting.
Iucretia-Large, jet black, highly flavored and hardy; berries ripen before raspberries are gone, sweet and luscious throughout with no core. The best, most dependable and profitable of all Dewberries grown. The Lucretia Dewberry has received the highest praise from the best horticulturists in the country.

\section{GOOSEBERRIES $\|$ G}

Gooseberries should be planted in good, rich soil and well manured once a year. Pick regularly, thoroughly cutting out all dead-wood and surplus branches. Plant in rows 4 feet to 6 feet apart in row. It is well to mulch heavily in the fall. Plants are hardy, rugged and easily grown.

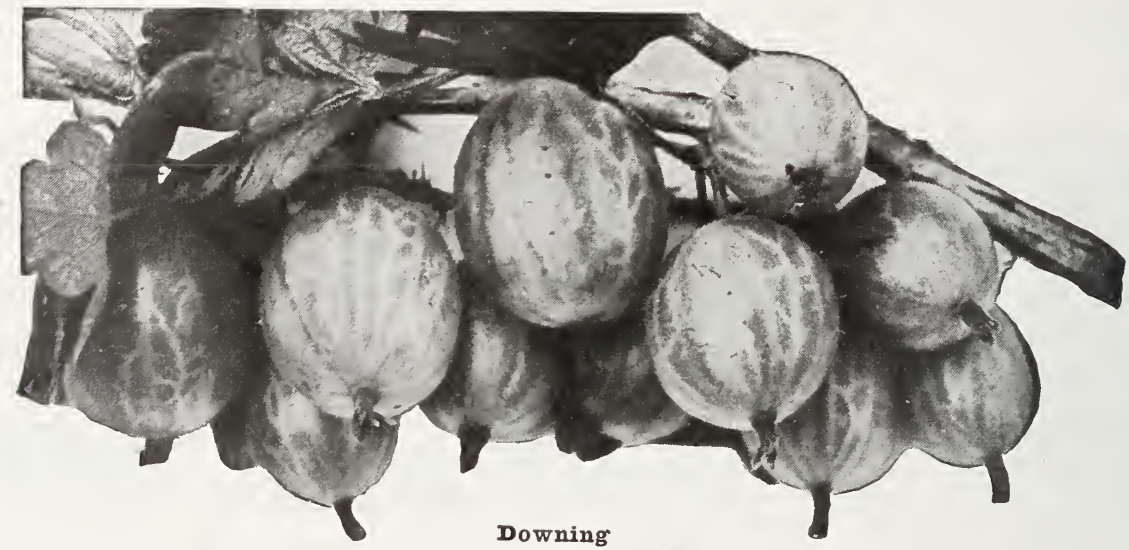

Carrie-Variety for Minnesota; berries fair size, though not large, of a bright maroon color; excellent quality. Most valuable gooseberry for jams, jellies and canning.

Champion-Large, round; greenish-yellow; the quality is very good for all purposes. The leading sort in some sections. Bush vigorous and free from mildew and one of the most productive. Midseason.

Downing-Large; roundish; light green, with distinct veins; skin smooth; flesh soft, juicy and very fine flavored; highly esteemed for home use and market. Bush vigorous and productive. Midseason.

Houghton-Medium; roundish; pale red; tender, sweet, very good, and berries are very deliciously flavored. Very profitable for canning or for catsup. Bush vigorous, slender and rather spreading. Enormously productive. Seldom mildews. Midseason.

Industry-Very large; red; hairy; fine quality; excellent flavor; extensively planted for market. Bush upright, strong and productive. English sort and somewhat liable to mildew. Early.

Josselyn (Red Jacket)-Large, pale red when ripe; oblong; very highly flavored. Bush a strong, vigorous grower; hardy and a wonderful cropper. Early.

Pearl-Medium size; greenish; quality the very best; sweet enough for dessert when ripe. A desirable sort. Bush strong grower and productive.

Smith (Smith's Improved)-Large; oval; light green with bloom; flesh moderately firm, sweet and good. Bush a vigorous grower and very productive. An excellent berry. Early.

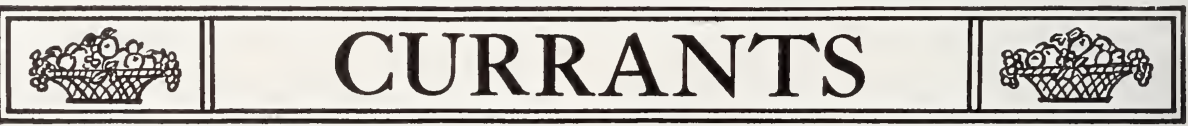

The currant is one of the most reliable of small fruits. They mature just before raspberries and can be used either raw or cooked. Being hardy, they do not winter kill, are easy of cultivation and require little care. They can be grown in any good garden soil. The market is never over-supplied. Prune out dead wood, and mulch heavily. If currant worms appear dust with hellebore. 


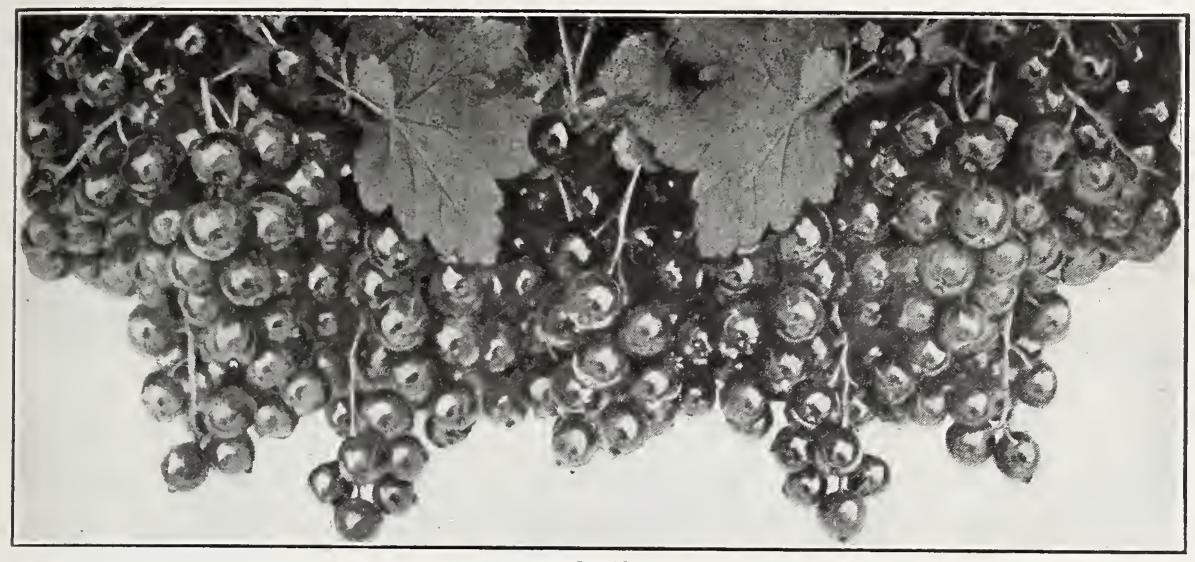

Perfection

Champion-Very large; black; flavor of of highest quality; one of the very best fruit particularly delicious; for kitchen and prized for dessert use as well as marand market. Bushes large; fruit hangs ket and kitchen. Bush vigorous and prowell on the bushes and bears severe prun- ductive, with long fruit clusters. ing without injury.

Cherry-Very large; red; rather acid; bushes short, erect; stout, vigorous and productive.

Fay-Very large; red; fine flavor; a great market currant; universally praised. Bush a cross between Cherry and Victoria, and very prolific.

London-Rather small; red; excellent for market and kitchen; ships any distance. Bush hardy and is planted extensively in northern climates; retains its foliage throughout the season; very prolific.

Ferfection-Large; upright red; quality very superior, rich, mild, sub-acid. Bush good grower and healthy foliage; long clusters and productive.

Red Cross-Very large; red; sweet and

victoria-Large; bunches extremely long bright red of highest quality. Very valuable for home garden because it hangs on bushes a couple of weeks after ripening.

White Dutch-Medium large; white; one of the very best quality sorts; especially prized for dessert use; very popular. Bush productive.

White Grape-Large; white; sweet or mild sub-acid; very good quality and popular for dessert and kitchen, and well known in market. Bush low and spreading. Dark green foliage; very productive.

wilder-Very large; bright red and attractive; a splendid market sort; not so acid as most. Bush very productive; large bunches; ripens rather early; fruit keeps well.

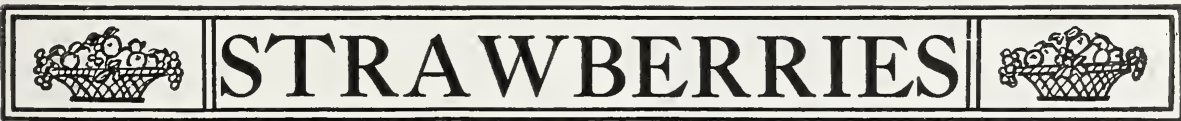

Strawberries are one of the most common and extensively used varieties of our small fruits and as a commercial proposition are grown in large quantities at very satisfactory profit. Are most fully enjoyed when picked fresh from the vine fully ripe. Growing them presents many problems that makes it an interesting occupation of itself, but it is by no means hard to secure wonderful results. It is a great fruit for large profits on small spaces and deserves the cultivation by every person having ground which can be utilized.

Everbearing varieties are receiving a great deal of attention and berries were being picked in Michigan this year all through the fore part of October. The Everbearing berries shorid be transplanted each year in order to insure their fruiting, but the extra time and attention is well repaid for by the lucious results.

Aroma-Large; dark red; uniformly roundish, heart shaped; flesh firm and of very good quality. Stands shipping well; plants vigorous and very productive; blossoms rich in pollen and is good fertilizer for imperfect varieties. Late.

Bederwood-Medium size; light scarlet; rather roundish; flesh red, quality excellent. Recommended for dessert and market. Perfect.

Brandywine-Very large; crimson; flesh firm and of a peculiarly pleasing flavor; popular on the market. Plants require 


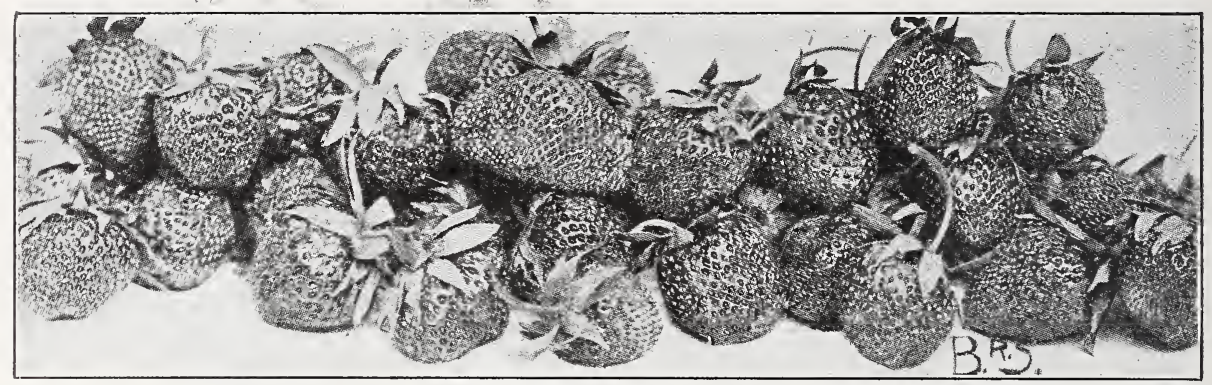

strong and high culture to get satisfactory results. Perfect. Medium late.

Bubach-Very large; scarlet; flesh moderately firm and of good quality, red clear through. Grown as a market variety all over the country. Vines yield well and are reliable. Imperfect. Midseason.

Crescent-Medium size; light scarlet; flesh fairly firm and of very good quality. Especially desirable for market. Plant a strong grower and can be relied upon for crop. Especially desirable for sandy soil over-crowds on rich. Imperfect. Midseason.

Dunlap-Medium size; dark, glossy red with golden seeds; flesh reasonably firm, red and of excellent flavor. Highly recommended for all purposes. Productive and hardy. Midseason.

Gandy-Large, light crimson; flesh of firm, good quality. Plants vigorous but should be planted on swamp or moist, clay soils. Perfect. Late.

Glen Mary-Very large; crimson with

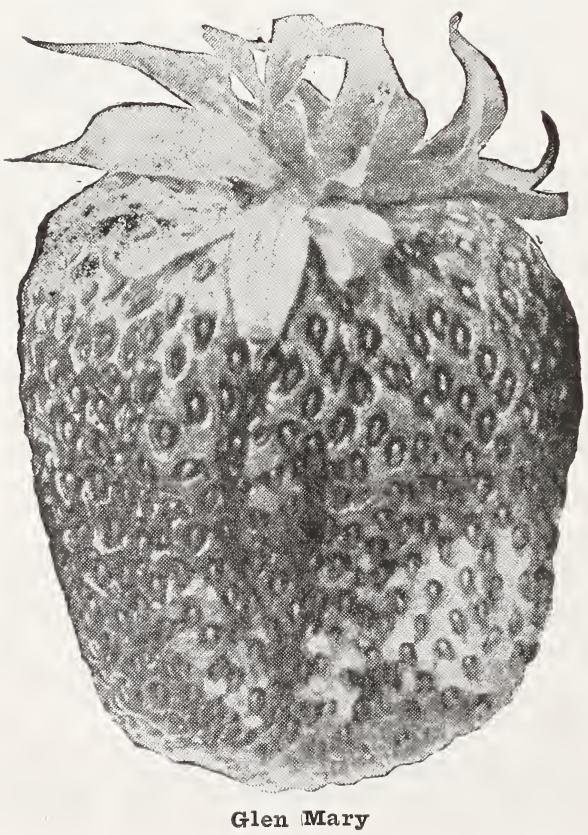

prominent seeds; flesh firm and juicy. Recommended for dessert and market; of the very best quality. Plants strong and vigorous, thriving on all kinds of soils. Perfect. Midseason.

Haverland-Large, scarlet or crimson. Plant vigorous grower; resists frosts well and yields good crops. Perfect. Midseason.

Inovett-Medium to large; dark crimson; flesh firm, richly flavored and juicy. Strong. It is an old and well tried variety and does well throughout the north. Perfect. Late.

Michigan's Pride-Large and oblong, bright, glossy red; flesh firm and of good quality both for canning and shipping. Plant a splendid producer and rich in pollen. Perfect. Late.

Sharpless-Very large; light red; flesh moderately firm, sweet and excellent.- An old and well known variety of the very best quality. Needs good rich soil. Perfect. Midseason.

\section{Everbearing Strawberries}

Americus-Large; firm; uniform shape; bright red through and through; has native wild strawberry flavor; very productive from May until hard freezing weather. Claimed by some to be the best of everbearing strawberries.

Erancis-Medium to large, rather long; glossy red; aromatic flavor; fruit stems long and cannot hold large specimens off ground.

Iowa-Medium to large; scarlet; firm, and quality fine; plants thrifty and very productive; fruit has been picked in Iowa as late as December 1 . It is one of the highly recommended sorts.

Productive-Fairly large; light red; heart shaped; very firm and delicious; imperfect blossoms and requires a perfect plant to go with it for fertilization; plants are large, healthy and enormously productive. Imperfect

Splendid-Large; rlark crimson; flesh firm and red, shadins white in the center. Melting and fine flavor. Perfect. Early to late.

superb-Very large, dark red and glossy; fine quality. It begins to bear in June with immense crops and continues until late in fall. It is one of the heaviest bearers of berries in June as well as a remarkable fall bearer. Will produce a fair crop of fruit the first summer. 


\section{DECIDUOUS TREES}

The planting of well selected trees is a duty each land owner owes to himself and posterity, and a duty which should not be delayed, the sooner planted the longer both yourself and the public may enjoy them.

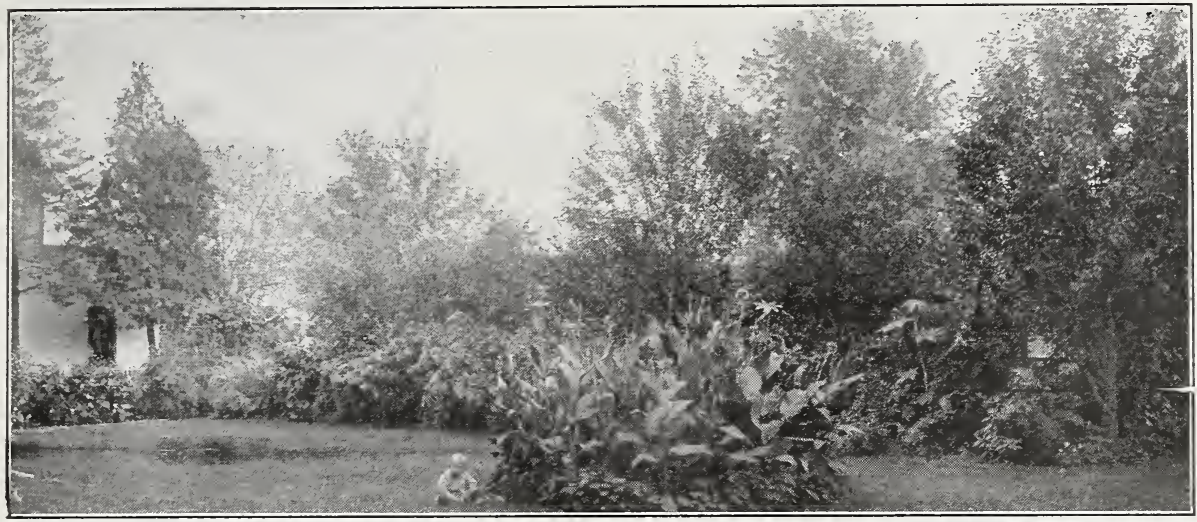

\section{ALMONDS}

Hard Shell-The tree is very showy when in bloom. The kernels of the nuts are large, plump and sweet. Hardy.

Soft, or Paper Shell-Encloses as fine a nut in a softer shell. Needs protection.

\section{CHESTNUTS}

American sweet-The nuts of this tree form quite an item in our commerce. Although smaller than some other sorts they are sweeter and more delicately flavored. This Chestnut is also a grand timber and ornamental shade tree, spreading, in midsummer, billowy masses of creamy tragrant catkins above its large, deep green leaves, making a most beautiful specimen on the lawn.

Spanish-A handsome, round-headed tree producing abundant crops of very large nuts that sell readily for good prices. Not so sweet as the American in nut, and not so hardy in tree.

\section{FILBERTS (Hazelnuts)}

The filbert succeeds well on almost all soils, the little trees or bushes bearing early and abundantly.

English-Most hardy and generally satisfactory over a wide territory. The nuts are nearly round, rich-flavored and toothsome.

\section{HICKORY}

Shellbark-In flavor and quality of kernel this is generally esteemed the choicest of our native nuts-of all nuts, some experts have said. The tree is a handsome stately shade tree, with tough white wood of great strength and elasticity, marketable at high prices.

Pecan-This species of the Hickory may well rank first among our native nuts in value and cultural importance. The trees grow fast, are reasonably precocious in development and bearing, and produce large crops of thin-shelled nuts that are full-kernelled and delicately flavored.

Faragon (Great American)-The most widely planted and most uniformly successful variety yet cultivated in the United states. The three or more broad thick, handsome nuts in each burr are of extra size and quality.

\section{WALNUTS}

American Black-The large, oily nuts are borne in heavy crops. They are much relished by children, and always marketable at a fair price. The tree grows quite fast; its dark rich wood is exceedingly valuable.

English-A fine, lofty-growing tree, with handsome, spreading head; produces large crops of thinshelled, delicious nuts which are always in demand at good prices. Not hardy enough for general culture north.

Siebold's Japan-Of the finer imported Walnuts this is the species best adapted by its hardy, vigorous habit for general culture in our country. It grows with great vigor, assuming a handsome shape without pruning, and has withstood a temperature of 21 degrees below zero without injury. Its nuts are considerably larger than the common hickory-nut, and are borne in clusters of fifteen to twenty. The shell is a little thicker than that of the English Walnut, which it resembles in a general way; the kernels are meaty, delicate, and can be removed entire. The trees begin to bear when two or three years old.

White or .Butternut-The nuts are large, long, oily and nutritious. The lofty, spreading tree is one of our finest natives, valued for its tropical appearance and beautiful wood, as well as for its nuts. 


\section{AILANTHUS (Tree of Heaven)}

A. Glandulosa-From Japan; a lofty, rapid growing tree, with long, elegant, feathery foliage; free from all diseases and insects. One of the most distinct of ornamental trees.

\section{ALDER (AInus)}

European or Black-A vigorous and rapid growing tree, leaves dull, dark green, turning to yellow in autumn. Of great value for planting in cold, damp ground.

Smooth (A. Rugosa)-A small tree; very valuable for planting in low, damp ground or along a water side. Flowers in late winter or early spring.

\section{AMELANCHIER (The Service Tree)}

Service \$erry (Amelanchier Botryapium)-A tree with upright or spreading branches, leaves dark green, flowers appearing with the leaves; the fruit is edible An ornamental tree of great hardiness and especially effective on steep hillside.

Shade Bush (A. Anadensis)-Has small, spreading branches, dark green turning to yellow in fall; white flowers appear with the leaves; the fruit is edible, bright red when fully grown, dark purple when ripe. One of the earliest to bloom.

\section{ASH (Fraxinus)}

white (Americana)-A well known native tree; very straight, with broad, round head and dense foliage. A beautiful and desirable shade tree.

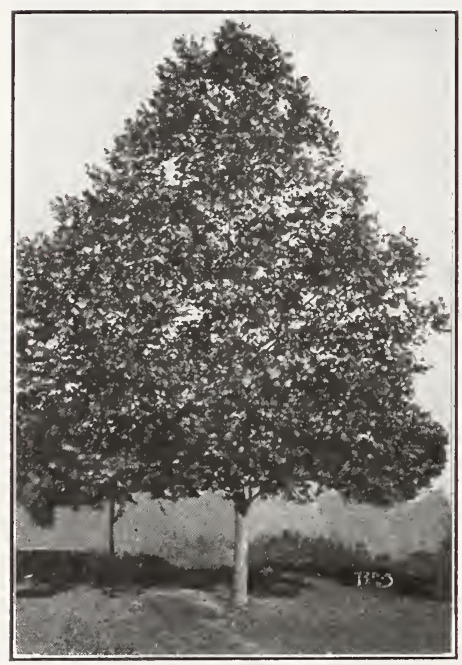

White Ash

Flowering Ash ( $\mathrm{F}$. Ornus) - A small tree producing dense terminal panicles of fragrant white flowers in May or June; leaves dark green. Very showy.

\section{BEECH (Fagus)}

American (Americana)-A large, stately tree with smooth, gray bark and a compact, round head. Grows very high and is one of the handsomest for street or awn.

European (F. Sylvatica) - A large and beautiful tree, with dark green, glossy leaves. Rather more compact dnd of slower growth than the American. A grand lawn tree.

\section{BIRCH (Betula)}

European white (Betula Alba)-A beautiful tree with white bark and in age spreading and pendulous ranches. Very effective for landscape.

Purple Ieaved (B. Tropurpurpea)-A vigorous tree with purple leaves, contrasting - strongly with the beautiful white bark.

\section{CATALPA}

Chinese (C. Bungei)-A remarkable dense round headed bush, grafted upon straight, upright stem. Very hardy and effective for lawns or formal gardens.

Fardy (C. Speciosa) - A variety that is being grown in the west for timher as well as posts and shade. Has broad, deep green leaves and beautiful large blossoms, making it highly ornamental for lawns or street. Rapid grower.

\section{CHERRY (Cerasus)}

Double White Flowering-A small tree of garden origin, with double white flowers in great profusion. More beautiful and lasting than the common cherry. of great service as cut flowers.

\section{CHESTNUT (Aesculus)}

Common or white rlowering-A handsome tree of regular form with showy foliage and covered in the spring with panicles of white showy flowers marked with red. As a lawn or shade tree it has no superior.

Ohio Buckeye (A. Glabra)-A native of Ohio, forming a large size tree, leaves light green above and darker beneath, turning yellow in autumn; flowers

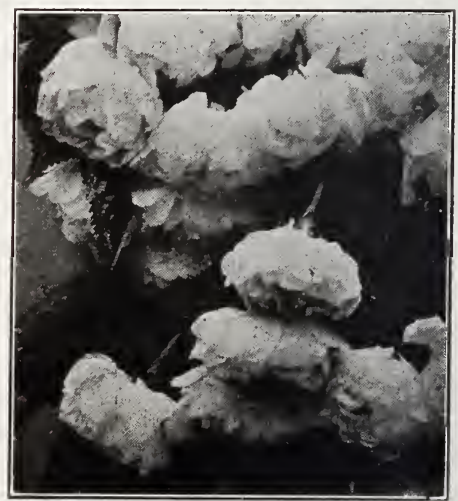

Double Flowering Cherry 
in large clusters; nut husk is thickly covered with spines.

\section{THE FLOWERING CRAB (Malus)}

Flowering Crab (M. Floribunda)-A small tree, native of Japan; leaves bright green and lustrous, fading with tones of yellow and bronze; flowers rose red, produced in great abundance; fruit about the size of a pea.

Bechtel's Double Flowering Crab (P. Augustifolio) -Tree of medium size covered in the early spring with large beautiful and fragrant flowers of a delicate pink color. One of finest trees in cultivation.

\section{DOGWOOD (Cornus)}

Alternate-Ieaved Dogwood (Cornus Alternifolia)A small, flat-topped tree. Leaves oval, bright yellow-green, turning yellow and scarlet in autumn. Flowers cream-color, expanding in late spring or early summer, disposed in terminal flat cymes. Fruit bluish black. Very ornamental.

\section{ELM (UImus)}

American-A magnificent tree growing 80 to 100 feet nigh, with drooping, spreading branches.

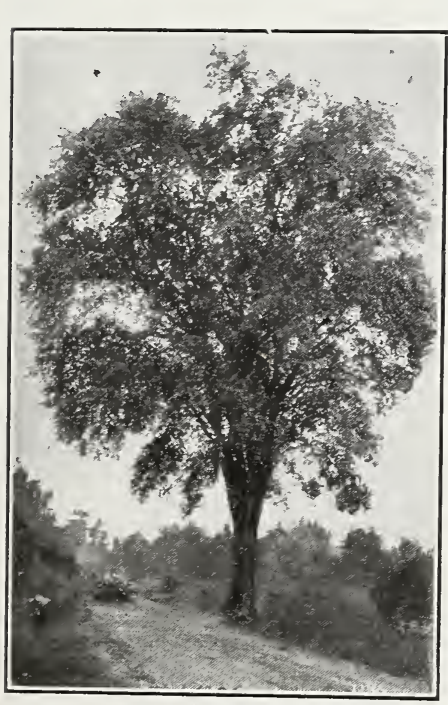

One of the fast growing and grand lawn or street.

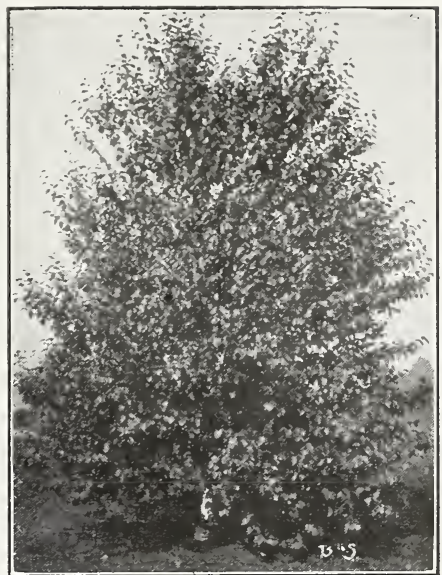

Birch

English (U. Campestris) - A large tree with spreading branches, forming a round-topped crown; leaves deep green and hold their color late.

Scotch or Wych (U. Montana)-A large, handsome tree with spreading branches forming a round-topped crown; leaves very rough but remaining a dark green until late in the season.

\section{HACKBERRY (Celtis)}

American Nettle Tree-A handsome tree with stout spreading branches, forming a round-topped crown; leaves almost like the apple, but more pointed; fruit resembles a small blackberry. Tery desirable for street planting.

\section{KENTUCKY COFFEE TREE}

Kentucky Coffee Tree (Gymnocladus)-A very ornamental tree of upright, rapid growth, with rough bark and coarse branches; foliage bluish-green; flowers white, followed by long pods which hang on the tree all winter.

\section{KOELREUTERIA}

Varnish Tree-A small, hardy tree with a round head and large panicles of showy yellow flowers the end of July. Grows twenty-five to thirty feet tall. American Elm

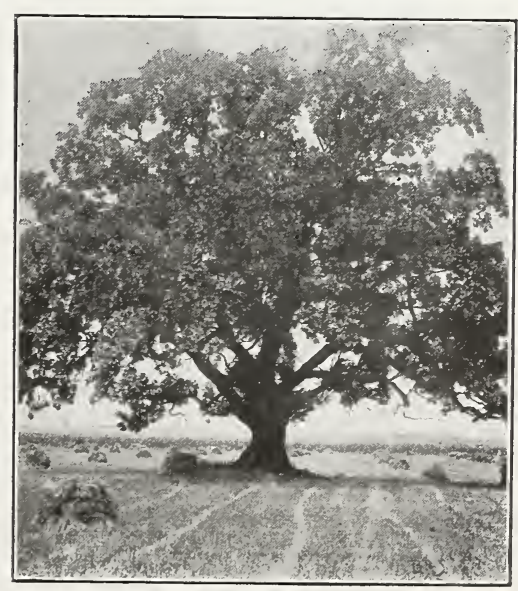

Leaves bright green fading to yellow and bronze in the fall. Nakes a rather pretty lawn
tree.

\section{LARCH (Larix)}

American or Tamarack-A tall, slender tree that is best at home on wet or damp soil; leaves pale green in tufts fading and falling in autumn. Cones globular, two-thirds of an inch long.

\section{LINDEN (Tilia)}

American or Basswood (Tili Americana)-A large tree forming a broad, round-topped crown. Leaves broadly oval, dark green on top and light beneath, turning yellow in autumn; creamy flowers in summer, and very attractive to the honey bee. A grand tree everywhere.

European (L. Europea)-A native of the Alps with a conical head; is esteemed as a timber variety as well as a graceful landscape and park tree. Only suitable for well drained soils as wet, heavy soils do not insure good growth. 


\section{LOCUST (Gleditschia)}

Honey Iocust (G. Tricanthos)-A rapid growing native tree with power ful spines and delicate foliage, the greenish flowers which appear in early summer are followed by flat pods eight or ten inches long. Used extensively for hedges as well as an ornamental.

\section{LOCUST (Robina)}

Black Locust (R. Pseudacacia)-A rapidly growing tree that reaches a large size and is valuable for timber as well as an ornamental. Flowers which appear in June are yellowishwhite and very fragrant.

\section{MAGNOLIA}

Chinese White (M. Conspicua)Shrub-like when young but gradualiy forming a medium size tree. Superb white flowers cover the tree thickly in April.

Cucumber Tree-A splendid pyramidal tree tinat grows to a great height, flowers yellowish-white, and fruit resembles a cucumber. A most valuable hardy shade tree.

Sweet or White Bay (MI. Glauca)slender tree or very large shrub. Leaves oblong, shiiny green flowers large creamy white, fragrant.

\section{MAPLE (Acer)}

Norway Maple (A. Platanoides)-A very handsome tree attaining large proportions, its spreading branches form a dense, round head and is especially desirable for street or lawn planting. Has five lobe leaves, bright green, lighter underneath, and smooth on both surfaces, fading to yellow and gold.

Box Flder or Ash Ieaved Maple (A. Negundo) - A rapidly growing tree with

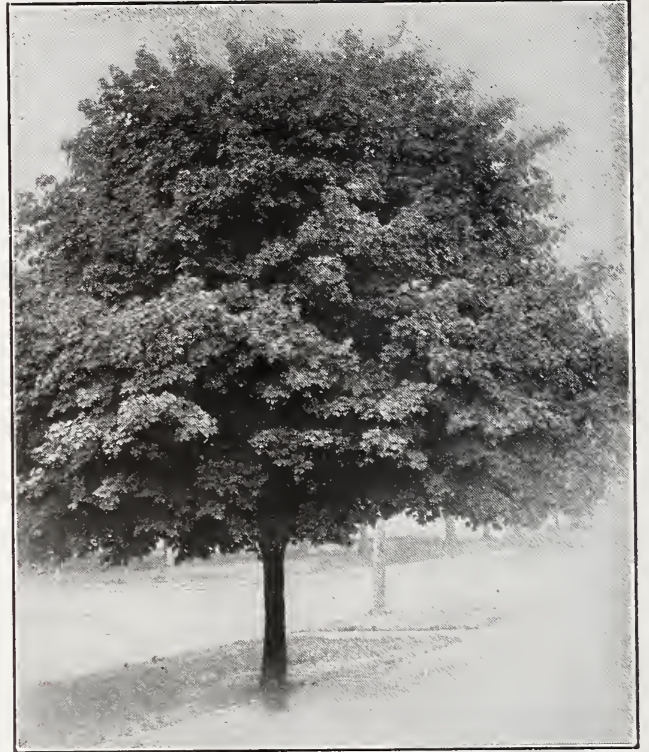

Norway Maple

spreading branches which grow to good size. Leaves smaller than other maples. Frequently planted as an ornamental, but especially popular as a wind break or for timber because very hardy, withstanding cold and drought.

Schwedleri (A. Platanoides)-A beautiful variety with very large bronze red leaves and young shoots of the same color: a vigorous grower and most effective ornamental tree; fifty feet high.

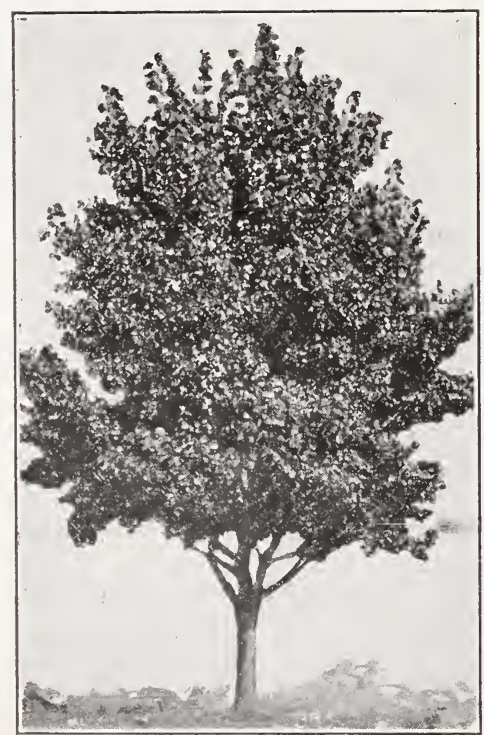

Carolina Poplar

Soft or Silver Leaved (A. Dasyca:pum)--A rapid growing tree of large size, irregular rounded form; foliage bright green; for streets and parks; attains about the same height as Norway.

Sugar or Hard (A. Saccharum) - A well known native tree, valuable both for the production of sugar and wood; very desirable as an ornamental shade tree.

Sycamore (A. Platanus)-A native of Europe; leaves large, deep green and smooth; bark smooth and an ash grey color; rapid upright growth; a beautiful tree for street planting.

Weir's Cut Ieaved (A. Laciniatum) - A variety of silver-leaved and one of the most beautiful, with cut or dissected foliage; rapid growth, shoots slender and drooping; ranks among the best as an attractive lawn or street tree.

\section{MOUNTAIN ASH (Sorbus)}

European-A fine tree with dense and regular head; covered from mid-summer to winter with great clusters of bright scarlet berries.

American-A small tree with spreading branches, forming a round crown, leaves dark green, turning vellow in autumn, flowers white and flat cymes, followed later by showy clusters of bright scarlet berries. Especially adapted to the northern regions.

\section{OAKS (Quercus)}

White-The grandest of this genus of our American trees. A spreading, towering specie, growing one hundred feet high when fully developed with 
rugged, massive trunk and branches. The deeply lobed leares change to dark crimson in the fall.

Pin (Q. Palustris)-A magnificent tree for lawn and street planting. Deep green foliage which changes to a bright scarlet and yellow by autumn a most shapely and graceful tree, assuming the clrooping habit with age.

Red (Q. Rubra) -Makes a tree of great height eighty to one hundred feet; of large size and rapid growth; leaves dark, dull green, turning to orange and brown in autumn; acorns very large; a beautiful tree for park or street.

\section{POPLAR (Populus)}

Balm of Gilead (P. Balsamifera Candicans)-A strong growing spreading native tree; leaves broad and heart shaped green above and rusty white below; makes a good street tree.

Norway ( $P$. MFonolifera)-Pyramidal in form and vigorous in growth; leaves large, glossy, pale to deep green: valuable for street planting on account of its rapid growth.

Iombard (P. Fastigiata)-Attains a height of from one hundred to one hundred fifty feet; Well known for its erect, rapid growth and tall, spiry form; indispensable tree for landscape gardening to break the monotony of most other trees.

Silver Leaved (P. Alba Var. Nivea)-A tree of wonderful rapid growth and wide spreading habits; leaves large, glossy green above and white underneath; prefers moist soil, grows anywhere.

\section{REDBUD (Cercis)}

Judas Tree-A medium sized tree with large irlegular head shaped leaves; derives its name Red Bud, from the profusion of delicate, reddish-pink blossoms with which it is covered in early spring before the foliage appears. One of the finest ornamental trees. $4-6 \mathrm{ft}$.

\section{SYCAMORE}

American Sycamore or Plane (P. Occidentalis)_- well known tree, very common throughout the United States; leaves heart-shaped with small lobes, sharp pointed; branches wide and spreading; a rapid growing and beautiful tree with picturesque white or grey bark.

European Sycamore or Plane (P. Orien-

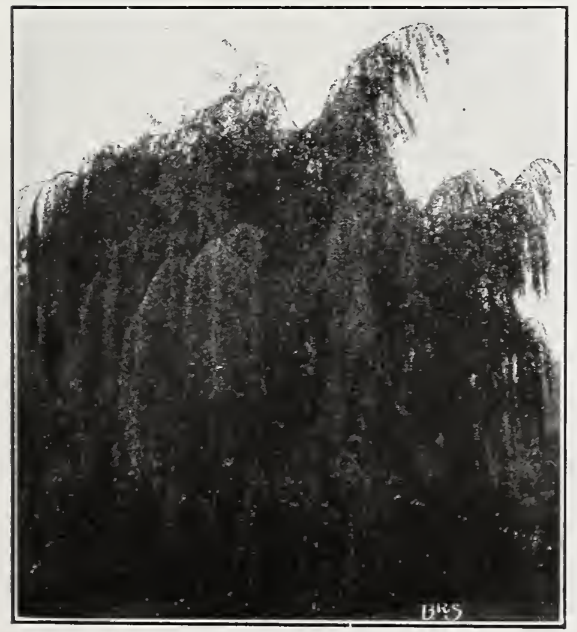

Weeping Willow

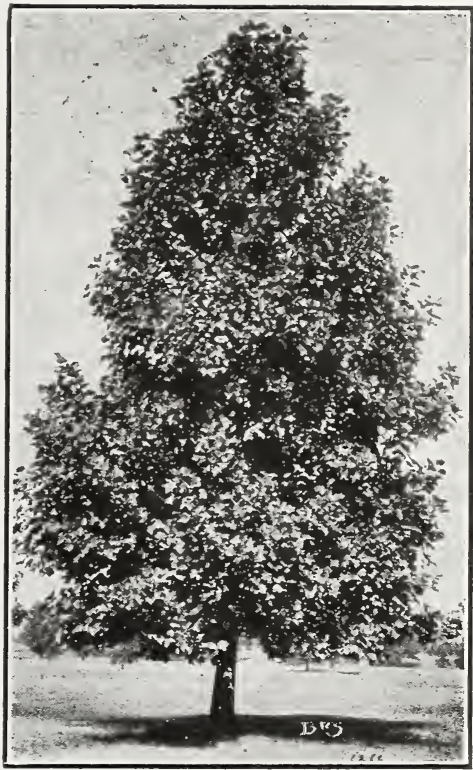

Tulip Tree

talis)_-A rapid growing tree, large and massive with a round-topped head; native of India and Europe and has been cultivated from time immemorial; bark whit ened; bright green foliage; very hardy and generally preferred to the American for lawns and street.

\section{THORN (Cratargus)}

Double white Thorn (L. Oxvacantha ver. Alba Flore Pleno) -A small tree with spreading spiney branches; very hardy and will thrive in a dry soil; this is the famous May thorn of English gardens and is very beautiful; double white rose plossoms cover the tree when in blorm.

\section{TULIP TREE (Liriodendron)}

Tulip Tree (L. Tulipfera) - A tall, pyramidal trunk rises to a great height and is clothed with a splendid foliage of large, glossy leaves; large, tulip-shaped flowers are borne in the spring, greenish yellow and orange. One of the most distinguished tall trees.

\section{WILLOW}

Iaurel Ieaved (S. Pentandra) - A medium sized tree with compact habits, leaves shiny dark green and fragrant when bruised, the odor resembling the Eay tree. One of the best willows for ornamental planting.

Rosemary (S. Incana) A shrub or small tree with a simmetrical round top; does not grow over eight feet tall: leaves narrow, bright green, silvery white beneath.

Yellow (S. Titellina) - A large tree with a bright yellow bark: forms a round head, and grows to verv large size. The conspicuous color of the bark gives it a pleasing contrast to evergreens or other trees in the Finter. 


\section{WEEPING TREES}

\section{ASH (Fraxinus)}

Furopean weeping-The common well-known sort; one of the finest lawn and arbor trees, covering a great space and growing rapidly.

\section{BEECH (Fagus)}

Weeping-A native of Belgium; a fine, vigorous and beautiful tree, attaining a large size.

\section{BIRCH (Betula)}

Cut-Ieaved Weeping-Trembling, vigorous and hardy. A most beautiful tree with its leaves trembling in the lightest breeze. Its bark glistening from bright foliage and sparkling in the sun.

\section{M.ULBERRY (Morus)}

Tea's weeping-A variety of the well-known Russian mulberry. Forms a perfect umbrellashaped head, with long, slender branches which droop to the ground parallel with the stem. Very beautiful and hardy.

\section{WILLOW (Salix)}

American Weeping-A dwarf, slender variety grafted five to six feet high; it makes one of the most ornamental of small weeping trees more hardy than Babylonian.

\section{ELM (Ulmus)}

Camperdown Weeping-One of the most distinct and picturesque of all our weeping trees. Grows well in almost any

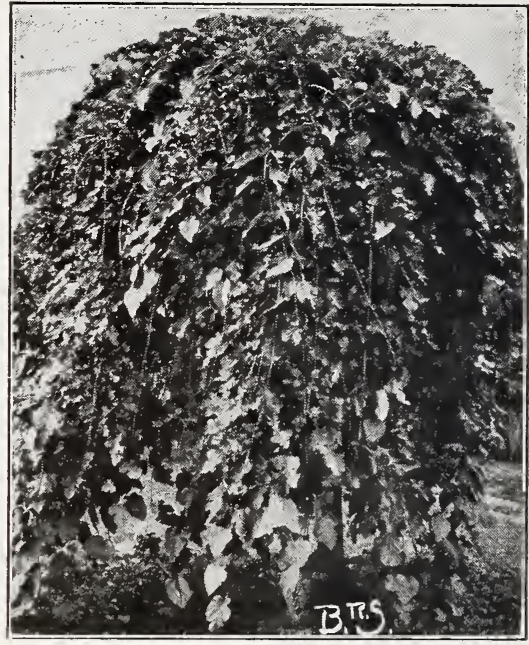

Weeping Mulberry

climate; is of fine and notable habit, the strong branches often sweeping out horizontally several feet before they curve downward, making a broad handsome head.

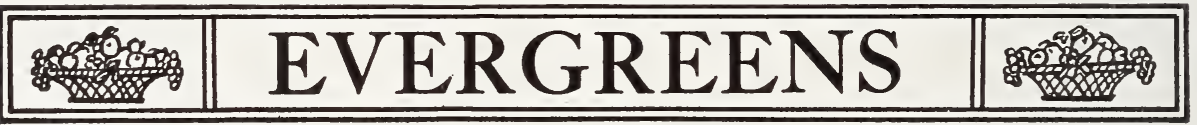

Considerable care must be exercised in transplanting evergreens and should never be set in the fall after the growth of other trees has ceased but their beauty and ability as wind breaks will repay the trouble.

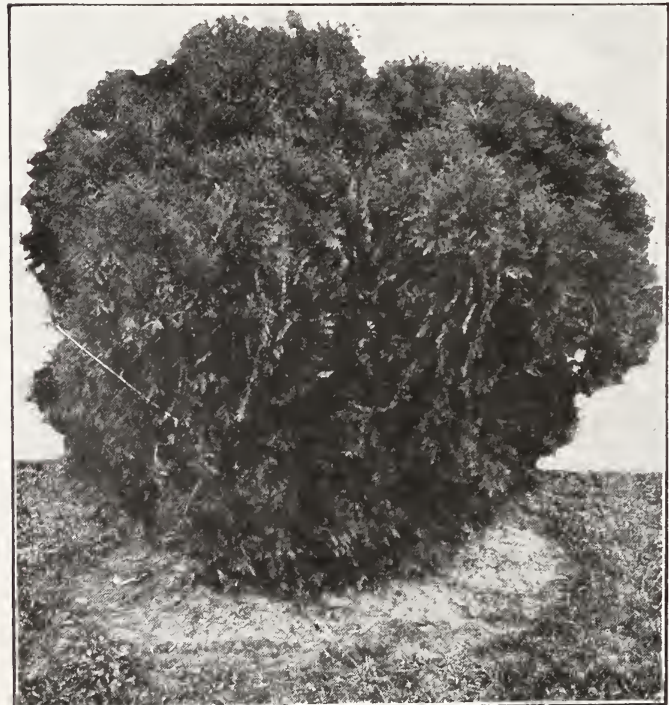

Globe Feaded Arborvitae

\section{ARBORVITAE (Thuya)}

American ( $T$. Occidentalis)-A beautiful native bright green; yellow-green beneath; valuable for screens and hedges.

Globe (T. Globosa)-A dense, light green evergreen of dwarf habit, grows naturally round like a ball; one of the best dwarf.

Golden ( $T$. Orientalis, Aurea)Broad, bushy grower, with deep golden foliage; ornamental.

Pyramidal ( $T$. Occidentalis, Pyramidalis - - A compact and narrow pyramidal tree; its branches are short and densely clothed with bright green foliage; very formal and attractive and the narrowest and most columnar of arborvitaes.

Siberian ( $T$. Occidentalis Siberica) -One of the best of the genus of this country; exceedingly hardy, keeping color well in winter; growth compact and pyradmidal; makes an excellent lawn tree.

\section{JUNIPER (Juniperus)}

Irish (J. Communis Hibernica)A slender, columnar form with numerous upright branches and invaluable in Italian gardens and whose architectural features are desired; foliage glaceous green. 
Red Cedar ( $J$. Virginiana)-Always popular and can be used ornamentally in a number of ways thriving well and making a fine appearance in soils or situations where other trees will not grow. Eighty to 100 feet.

Blue virginia Cedar (Glauca) - A very vigorous variety with silvery-blue foliage. This is one of the most beautiful forms of the red cedar, and makes a splendid specimen tree.

\section{PINE (Pinus)}

Austrian (P. Austriaca) -A tall tree, with a broad, ovate crown; leaves in pairs, about four inches long, rigid and very dark green; cones two or three inohes long, of a glossy yellowish-brown color. A fast growing, dense tree of great adaptability.

Bull (P. Ponderosa)A lofty tree from our western coasts, growing sometimes to 150 feet Hardy, quick growing, with long needles of silvery green.

Scotch (P. Sylvestris)Dense, broadly pyramidal, fifty to eighty feet high; luxuriant in growth, with strong, erect shoots and silvery needles.

White (P. Strobus)-The most ornamental of all our native pines. Foliage light, delicate silvery green: will grow in the poorest of sandy soils; a long-lived tree and a rapid grower.

Yellow (P. Echinata)-A tall, handsome tree with slender, often perpendicu- lous branches, forming a broad oval crown; leaves in twos and threes, dark green, three to four inches long, dull brown. Splendid for lawn and landscape.

\section{SPRUCE (Picea)}

Colorado Blue (P. Pungens)-One of the most beautiful and hardy of all spruces; in form and habits, similar to the white spruce; foliage a rich, light bluish-green.

Douglas (A. Douglasii)A native of Colorado; large, conical form; branches are spreading, horizontal; the leaves light green above, silvery white below.

Hemlock (P. Canadensis) -A graceful and beautiful native tree, with drooping branches and delicate, dark foliage, distinct from all other trees; a handsome lawn tree and it makes a ornamental hedge.

Koster's Blue Spruce (P. Pungenis, var. Kosteriana) -A type of the Colorado blue spruce; foliage is a rich and beautiful silveryblue, densely crowded on the many branches; very hardy.

Dwarf Norway (P. Excelsa Pygmaea)-Is a low, dense bush in which the branches are much shortened and crowned. A peculiar and interesting form.

Black Hills Spruce-Dark green perfectly hardy, very compact, the best for general planting. It is superior to any as a windbreak. Easily transplanted. A native of western South Dakota.

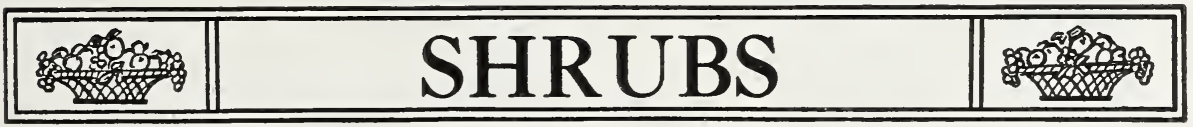

Beautiful effects are to be secured by the proper planting of hardy shrubs and we offer the most splendid selections.

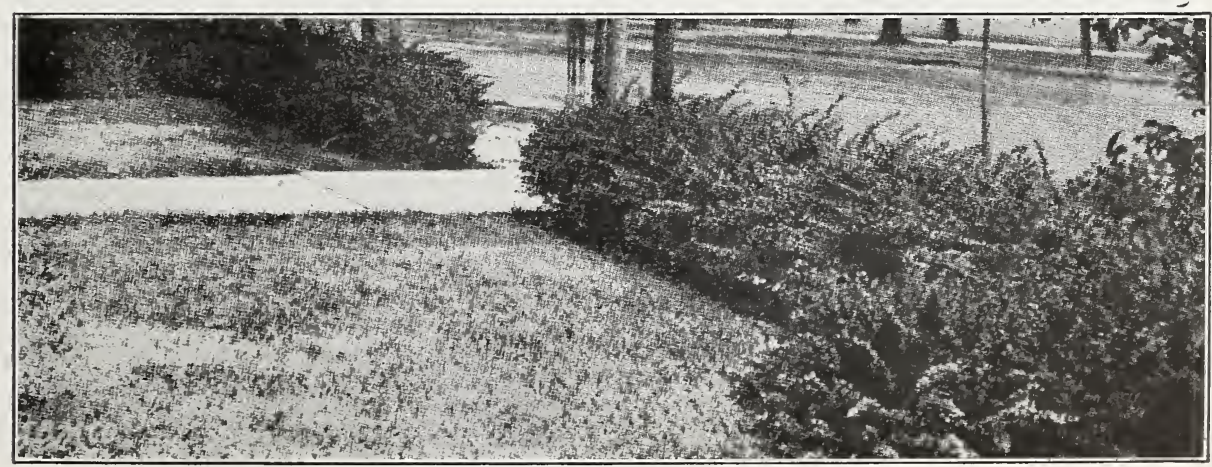




\section{AESULUS}

D w a r I Chestnut-An attractive and hardy shrub which grows from 5 to 6 feet tall. Flowers grow on long spikes and make a showing.

\section{BARBERRY}

The barberry makes a low, dense hedge which will stand any amount of trimming.

Canadian (B. Canadensis) - A native shrub which flowers in May. Handsome foliage; yellow flowers.

European (B. Vulgaris)-Grows 5 to 8 feet high with light green foliage; flowers yellow; berries dark red.

Japanese (B. Thunbergii - of dwarf habit, small foliage. changing to beautiful late fall.

\section{CORNUS}

Siberian Dogwood (C. Alba var. Siberica)-Grows 6 to 10 feet tall; dark green foliage, pale on under side. Blossoms in early summer with numerous flat-topped clusters of creamy white, followed by fruit of light blue or bluish-white. Branches blood red, very attractive shrub.

European Red Dogwood (C. Sanguinea) -Grows 8 to 10 feet high with purplish red branches and leaves marked with white. Blossoms in May and June are greenish-white in flat-topped clusters, followed by bunches of black berries.

\section{DESMIDIUM}

Sweet Pea Shrub (Penduliforum)-A low growing shrub whose top dies down in the fall, but comes up again in the spring, when it makes a valuable border, blooming in september.

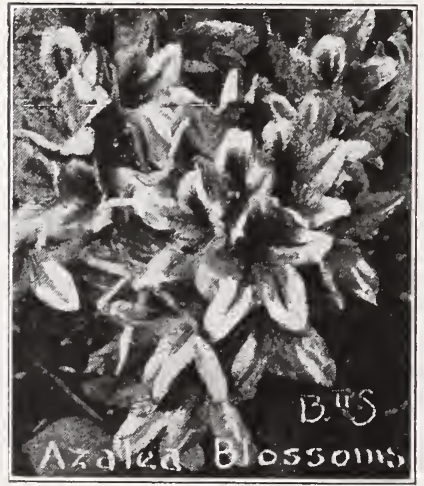

Azelia

\section{DEUTZIA}

Double White-Six to 8 feet high with numerous upright branches, rough, dull green leaves; blossoms in June with double, pure white flowers in erect panicles 2 to 4 inches long.

Double Pink-Similar to the preceding except that the outer row of petals are a rosy purple. Very showy.

Pride of Rochester-Six to 8 feet high, blooms in early spring with extra large, double white flowers. A distinct

and valuable variety.

\section{DIERVILLAS}

Flowering weigelia (D. Floribunhigh, with numerous u pright branches. Foliage dark green, blossoms in June with brownish-crimson buds which change to bright carmine.

Rose Colored weigelia (D. Florida)About six feet high with spreading habit; dark green foliage, blooming profusely with large, rose colored flowers.

Hybrida w e igelia -Grows 6 to 8 feet tall with numerous spreading branches, flowers trumpetshaped, large and showy. They can be had in a variety of colors such as:

Able Carriere ellow spot in throat.

Rose.

Eva Rathke-Dark Carmine.

Mad. Contourier-Yellowish white, changto pink.

ascal-Dark red.

\section{ELARAGNUS (Olesten)}

Russian Olive (E. Augustifolio)-Eight 2 feet high. Very hardy and prospers

Silver Thorn (E. Longipes)-Five to 8 feet high, of busy habits. Foliage dark green above, with silver beneath; very Blossoms in April or May; are creamy white, followed by edible fruit, for sauces. Fruit ripens in July.

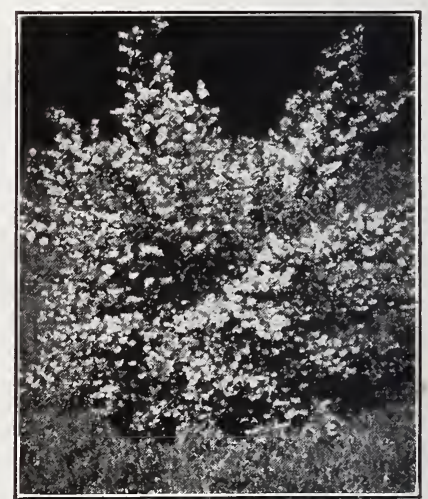

Deutzia 


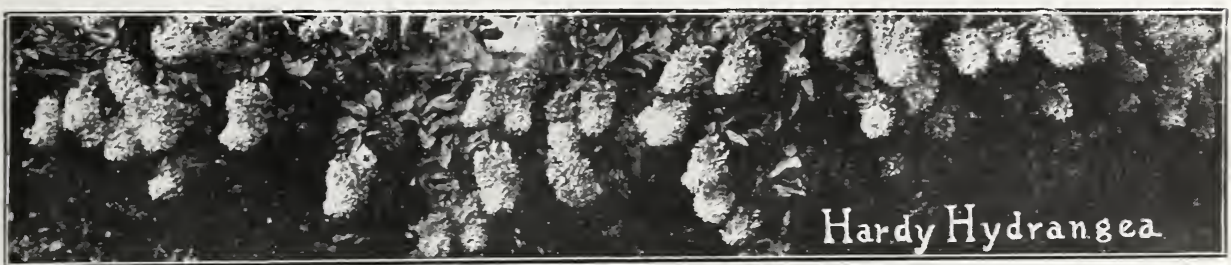

\section{EUONYMUS}

Burning Bush, winged (E. Elatus)-Six to 8 feet high, with corky winged branches. Foliage bright green, fading in autumn to gorgeous tones of red and crimson.

Strawberry Bush (E. Americanus)-Five to 8 feet tall. Erect with slender green branches. Foliage bright green with very rose colored warty fruit.

\section{FORSYTHIA}

Fybrid Golden Bell-Eight to 10 feet high with slender, arching branches. Foliage lustrous dark green; blooms very early in the spring, often before the snow is off the ground. One of the most showy shrubs in cultivation.

\section{HIBISCUS SYRICACUS}

Althea, Rose of Sharon-Eight to 10 feet high, resembling small flowering tree planted closely together they make a good flowering hedge. Blossoms late in the fall. A number of colors.

\section{HYDRANGEA}

Hardy (H. Paniculata Grandiflora)-A beautiful, tall shrub; foliage of bright shiny green; the flowers are borne in $\mathrm{Au}-$ gust and September in huge panicles from

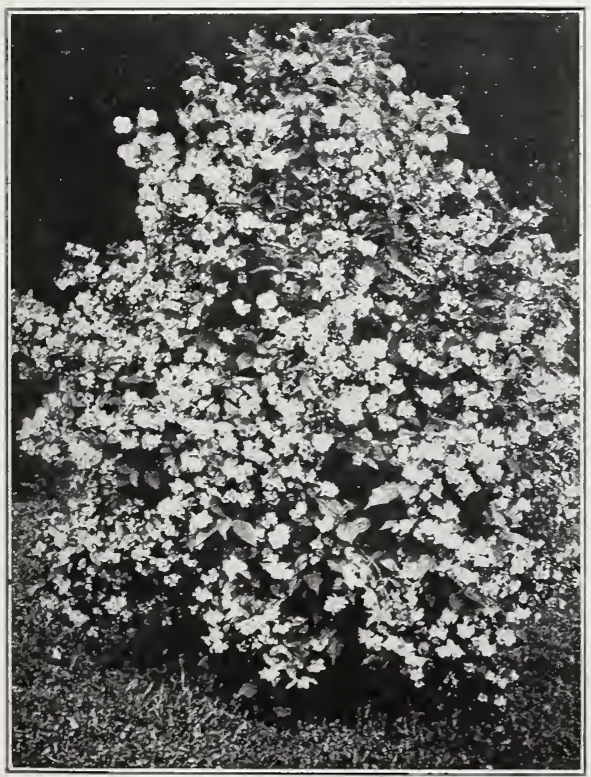

Syringea or Mock Orange
8 to 12 inches long. Beautiful as a border or can be grown in tree form.

Arborescens Alba Grandiflora-Resembles the Paniculata in general form and shape of flowers; borne in panicles of pyramidal shape from 5 to 8 inches in diameter and 8 to 10 inches long. White.

\section{LONICERA}

Fragrant Bush Honeysuckle (L. Fragrantisima)-Six to 8 feet high, with numerous spreading branches; foliage bright green; flowers white or light yellow; very fragrant.

Japanese Bush Foneysuckle (L. Worrowi)-Four to 6 feet high with spreading branches; dark green with light underside. Blooms very early in the spring.

Tartarian Honeysuckle (L. Tartariea)Eight to 10 feet high with numerous branches; bright green; blossoms in late spring with white or pink flowers.

\section{PRIVET (Ligustrum)}

Amoor River F'rivet (L. Amurense)-A valuable ornamental shrub for hedges and borders.

California Privet (L. Ovalifolium)-The well-known variety; vigorous and hardy: deep glossy green; useful for hedges and borders.

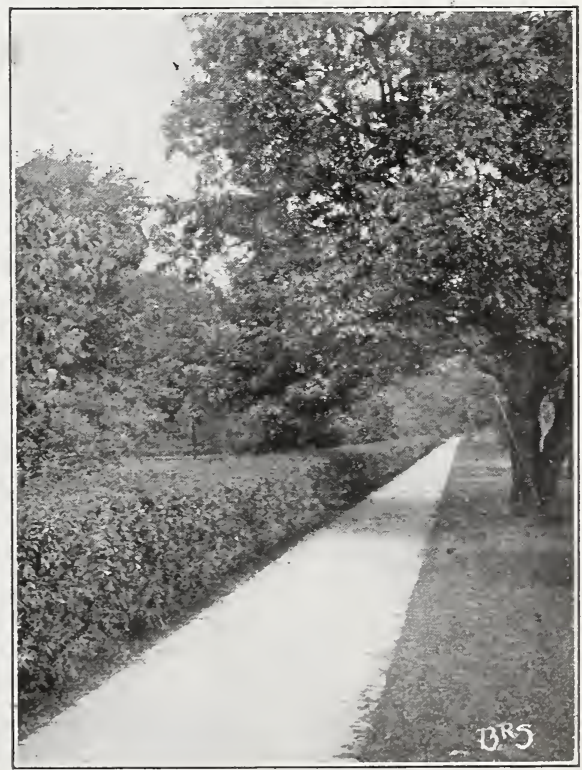

Privet 


\section{PHILADELPHUS}

Common Mock Orange or syringaEight to 10 feet high with upright or arching branches; foliage bright green; blossoms in May with great quantities of creamy white flowers.

\section{RHUS}

Fragrant SumacTwo to 4 feet high with branching habits; foliage bright green, fading to scarlet in autumn; blossoms in June, with yellow flowers

Purple Fringe or Smoke Tree-Ten to 12 feet high with spreading branches; foliage green, changing to brilliant red and yellow in autumn; the blossoms take the form of very bright, mistlike flowers, having the appearance of smoke at a little distance, and last during midsummer.

\section{RIBES}

Flowering Currant (R. Aureum)-Five to 6 feet high with upright branches; foliage lustrous green; blossoms in early spring with large and showy yellow flowers.

\section{SAMBUCUS}

American Elder (S. Canadensis)-Six to 10 feet, upright habit, the stems filled with white pith.

Golden Elder (S. Nigra Aurea)-Six to 15 feet; similar to the American, except the foliage is an attractive golden color.

\section{SPIREA}

Bridal Wreath-Five to 7 feet tall; foliage glossy green, orange in autumn; blossoms cover the entire length of the graceful, arching branches,

Japan Spirea-Is three to four feet tall; dwarf habit, of vigorous growth; blos-
Spirea soms in great profusion with flat clusters and for a long time; rose color.

Thunberg's Spirea - Three to 5 feet high with numerous $\mathrm{s} l$ ender branches, forming a dense feathery bush. Blossoms in early spring with pure white tlowers which cover it like a mantle of snow.

\section{Van Houteii's Spi-} rea-Five to 6 feet high with numerous spreading branches; foliag e, lustrous green; blossoms in early spring with large and showy flowers, followed by dark brown or black edible berries.

\section{SYRINGA}

Common Iilac Up to 25 feet in height; upright habits; blossoms in May with dense panicles of flowers of the most delicious fragrance.

Double Iilac-Are more dwarf than the single flower kinds; the flowers last longer but do not bloom so profusely.

\section{VIBURNUM}

Common Snowball-Six to 10 feet high, numerous upright stems; blossoms in the spring with globular clusters in great profusion.

Japan Snowball-Six to 8 feet high; vigorous, with spreading branches; foliage dark green with bronze margins; blossoms in spring with compact, globular white clusters four inches across. Better habits; preferred to old variety.

\section{EVERGREEN SHRUBS}

Rhododenaron-The most magnificent of the evergreen shrubs, with rich, green foliage and superb clusters of flowers.

Yucca Filamentosa-A tropical-looking evergreen; the flower stalk rises from the center about three feet. Hardy.

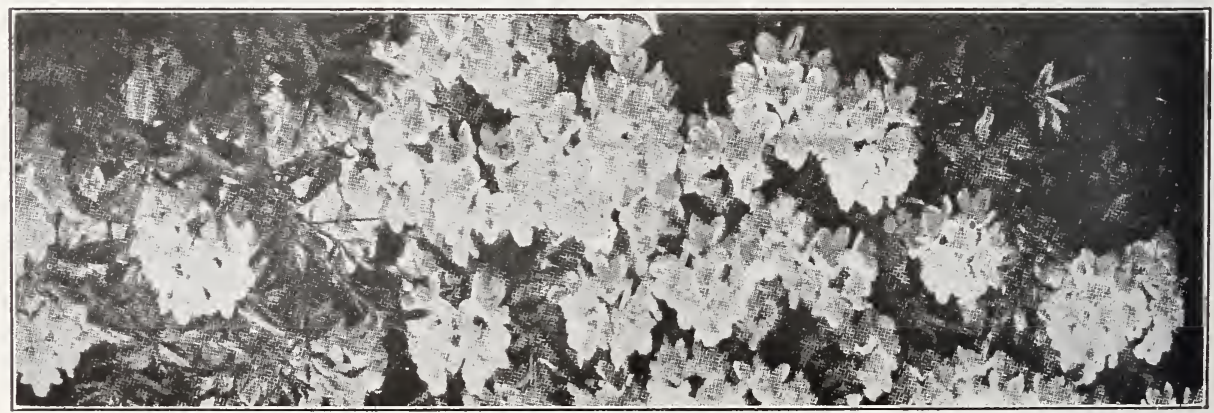

Rhododendron 


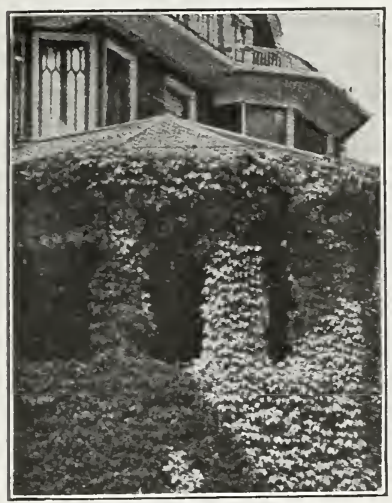

Boston Ivy

AMPELOPSIS

Emerican Ivy or Virginia Creeper-The well-known native vine with five-parted leaves that change to rich crimson in autumn; berries are blue-black. Very rapid glower and entirely hardy. One of the finest for covering walls, verandas or trunks of trees.

Boston Ivy (A. Veitchii)-A beautiful, hardy Japanese species. Leaves overlap one another, forming a dense sheet of green. It grows rapidly and clings firm$1 y$ to the smoothest surface with the tenacity of Ivy; the foliage is very handsome in summer and changes to scarlet in autumi.

\section{ARISTOLOCHIA}

Dutchman's Pipe A. Siphe) -A magnificent native vine of climbing habit and rapid growth. with magnificent light green foliage 10 to 12 inches in diameter, and curious pipe shaped, yellowish brow flowers.

\section{CLEMATIS}

Sweet Scented Japan Clematis (C. Paniculata) - Fiow ers are pure white, medium size, f:agrant and borne in immense sheetis in September. Foliage is clean and clossy of from 25 to $: 0$ feet in a single season and should be cut back to the ground each spring.

American White Clematis (C. Virginiana) - A re markably rapid c li m b ing plant, growing to the height of 20 feet, producing an immense profusion o

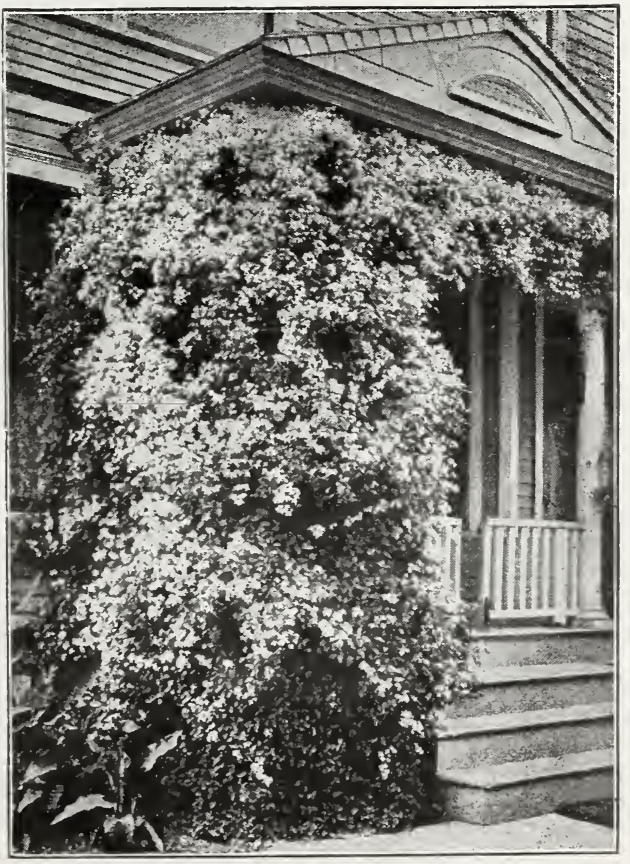

Clematis

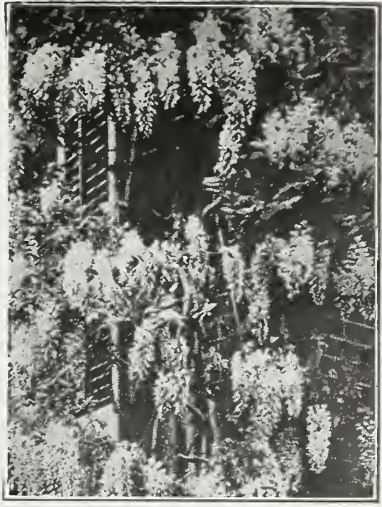

Wistaria
C. Jackmanni-Intense violet-purple, flowers are 4 to 6 inches in diameter when fully expanded; remarkable for its ricin, velvety appearance; an abundant and suscessive bloomer.

C. Madame Edouard Andre-Color a distinct crimson-red, flowers very large and velvety; has been called the crimson Jackmanıi.

\section{EUONYMUS}

Evergreen Vine (E. Radicans)--One of the finest evergreen vines, with sinall, rich green foliage and pink fruits in cells which separate and expose the scarlet arils covering the seeds, making a most attractive feature. It is a treasure. Used for vasels, baskets and borders of beds.

\section{LONICERA}

H $о$ n e $\mathbf{s}$ uckle, H a li's (Lonicera Halliana) -Blooms all summer, flowers almost evergreen.

$J$ a $p$ an Golden I e a v e d Hone $y$ suckle - A hanasome and desirable variety. F low e rs are creamy white and form festoons and masses.

\section{WISTARIA}

Chinese wistaria (W. Sinensis)-One of the most elegant and rapid growing of all climbing plants; attains an immense size growing at the rate of 15 to 20 feet in a season. Has long, pendulous clusters of pale blue flowers in May and June, and in autumn.

Japanese Wistaria (TW. Multijuga) A Japanese species w ith dark blue flowers. 


\section{ROSES}
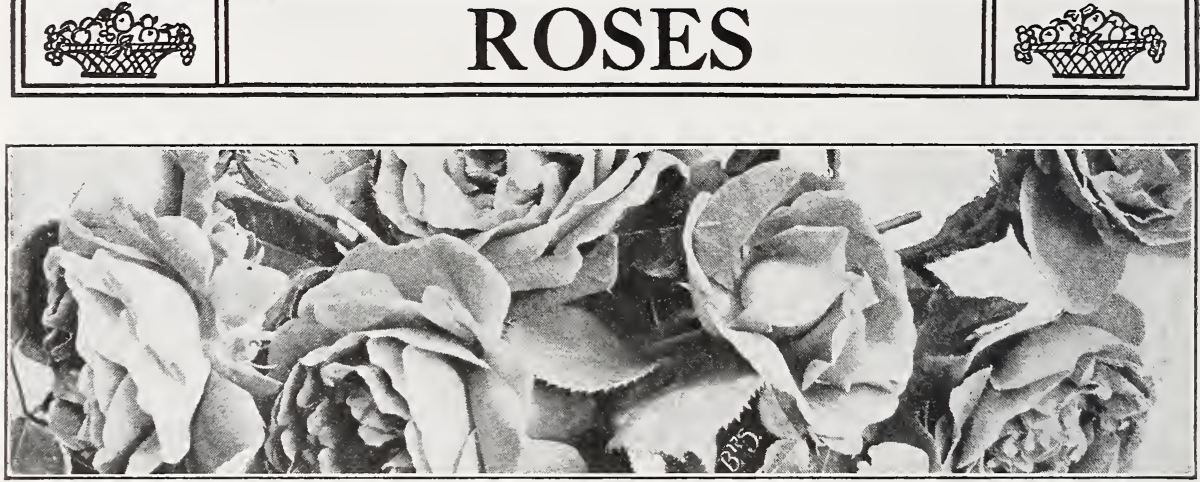

American Beauty-Deep pink, shaded with carmine; large, globular, delicious odor, desirable for forcing; not to be chosen for out doors growing.

Anne de Diesbach-Beautiful shade of carmine; large and showy, flower slightly cupped, particularly fine in bud. A vigorous grower, quite hardy; a good forcing rose.

Baroness Rothschild_Of light pink, flowers of immense size, perfect form and exquisite color, highly scented. One of the finest exhibition varieties, very hardy and late bloomer.

Clio-Flesh color shaded in the center with rosy pink. Large, globular form. Plant is strong and blooms freely, displaying its great flowers boldly on good stems against large, rich leaves.

Coquette des Alps-White tinged with pale rose, size medium, fine form, a free bloomer, dainty and attractive.

Earl of Dufferin-Rich crimson maroon with dark velvety shadings. Flowers are large, full, globe-shaped. Thick petaled and very fragrant. Grows well and blooms freely, with many handsome buds in autumn. One of the finest dark roses.

Frau Karl Drushki-Snow white, very large, perfect form. A vigorous grower and free bloomer. Bright, heavy foliag $\epsilon$

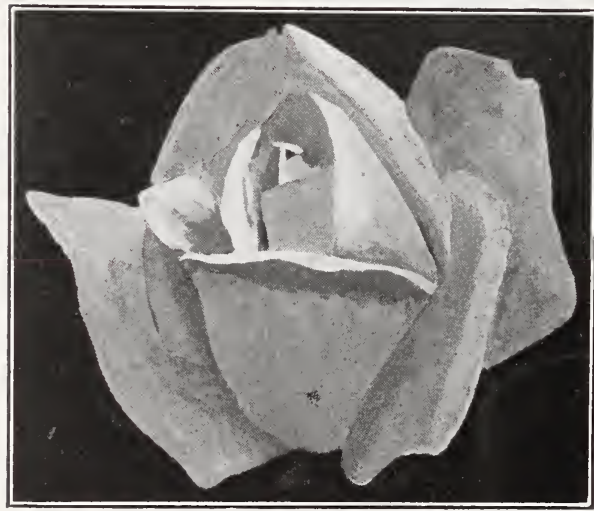

Frau Karl DrushkI and strong upright growth; flowers borne on long fine stems.

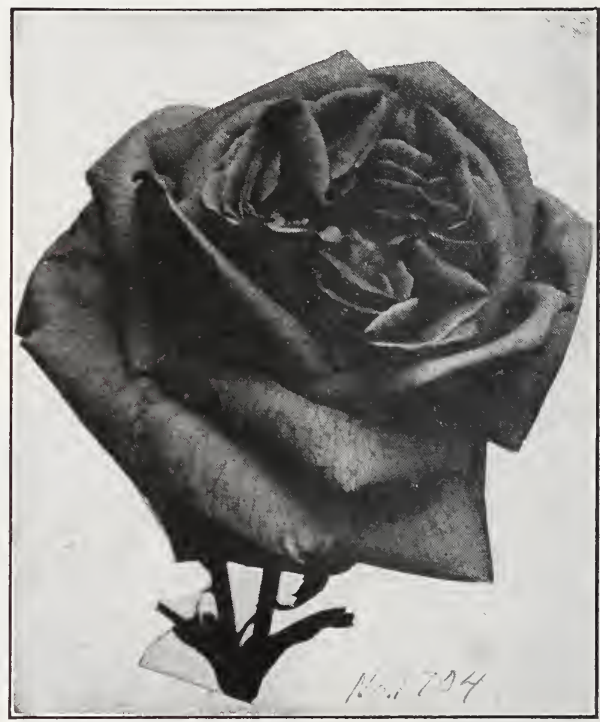

\section{American Beauty}

General Jacqueminot-Brilliant velvety crimson, large and extremely effective. A famous bud and forcing rose quite as well adapted for garden culture. Very fragrant and one of the most popular sorts grown.

General Washington-Deep crimson red, very large and double, opens wide and flat, very free bloomer.

John Hopper-Bright rose with carmine center; large and full. A profuse bloomer and standard sort. Free grower.

Margaret Dickson-A large and handsome winter rose of vigorous growth and magnificent form; petals very large, shellshaped and of great substance; fragrant. Foliage is large, dark green and rich, displaying the grand flowers well.

Marshall P. Wilder-Raised from the seed of Gen. Jacqueminot. Cherry color 
of good size, perfectly double and very fragrant. It is of vigorous growth and healthy foliage In wood, foliage and form of flower it resembles Alfred Colomb, but excels that variety in vigor, hardiness and freedom of bloom. One of the finest of its color.

Mrs. J. F. Laing-The color is a soft and delicate shade of pink; the flower is large, well formed, very fragrant and produced on good stems. The buds are long and pointed and extremely pretty. For outdoor planting this is one of the best roses introduced in many years. It blooms continuously in the open oround and is also valuable for forcing, the buds selling at high prices.

Magna Charta-Clear, rosy red, beautifully flushed with violet crimson; sweet fragrance.

Paul Neyron-The largest rose in cultivation, sometimes called the peony rose; color bright cerise red Often produces blooms five inches in diameter, very fragrant. The plant makes a strong, healthy srowth and has clean, glossy foliage, blooms almost without intermission from June until late October.

\section{EVERBLOOMING TEA ROSES}

Bridesmaid-Clear bright pink of an exquisite shade; large, full and globular, a constant bloomer. Grown chiefly for its large, solid and handsome buds; the stems are good, the foliage glossy. Excellent for bedding.

Duchess de Brabant-Salmon rose with amber shadings, a rich and peculiar color. 'The flowers are gracefully irregular and loose when expanded, but have elegantly pointed buds and a pervading peach fragrance. Extra vigorous and free in bloom in every way a beautiful rose.

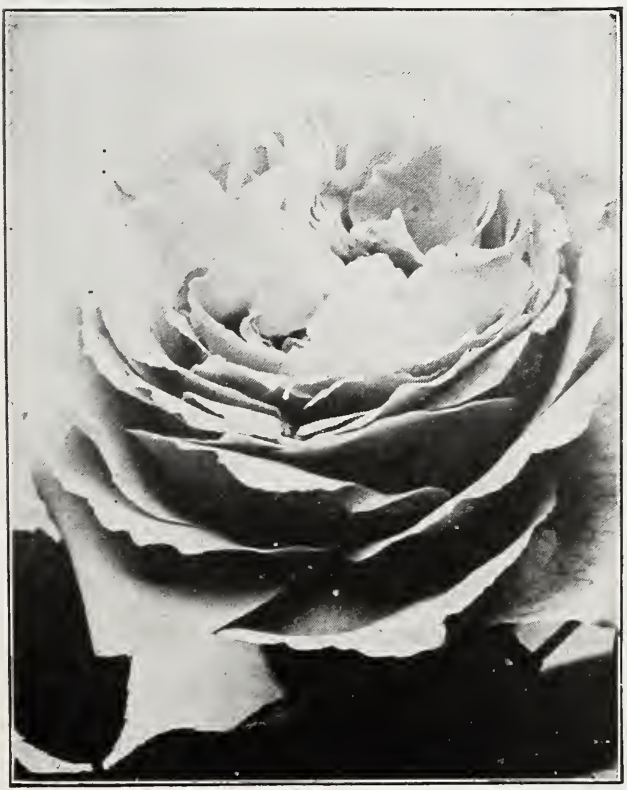

Mrs. J. F. Iaing

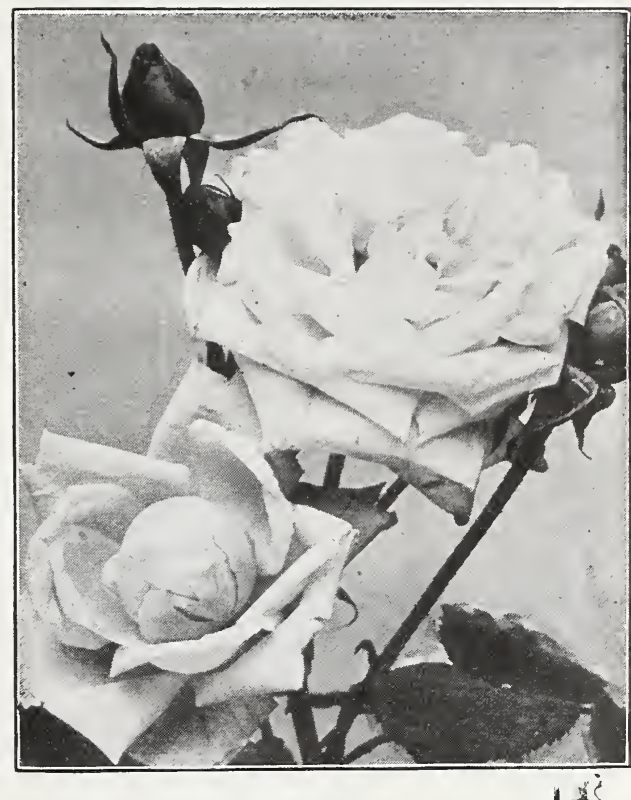

\section{Iafrance}

F'erle des Jardins-One of the most beautiful deep yellow roses in cultivation, varying from canary to golden yellow, in large, full, elegantly shaped buds and blossoms, very double and fragrant. A healthy free srower with beautiful foliage and unequalled in profusion of bloom.

The Bride-Most beautiful of the white Tea roses, and forced in numberless quantities every year. The great solid flowers remain perfect long after cutting, the stems are long and stiff, the foliage large, dark and glossy.

\section{RUGOSA ROSES}

Rosa Rugosa Alba-Pure white, single, having five petals and highly scented.

Rosa Rugosa Rubra-Bright rosy crimson, single, succeeded by large, brilliant berries of much beauty.

Madam George Bruant-White and fragrant buds long and pointed, semi-double when open; borne in clusters throughout the season; vigorous and hardy.

Consul Ferdinand Meyer-Double silvery pink flowers, large, cup-shaped; borne well above handsome Rugosa foliage. Exquisitely perfumed and perfectly hardy.

New Century-Flowers clear, flesh pink, three to four inches across, perfectly full and double. Perfume of sweet briers and is one of the most constant bloomers of its class.

\section{M.OSS ROSES}

Admiral Dewey-Dark red, very vigorous, one of the best.

Crested Moss-Deep pink buds surrounded with a mossy fringe and crest; exquisitely fragrant. 


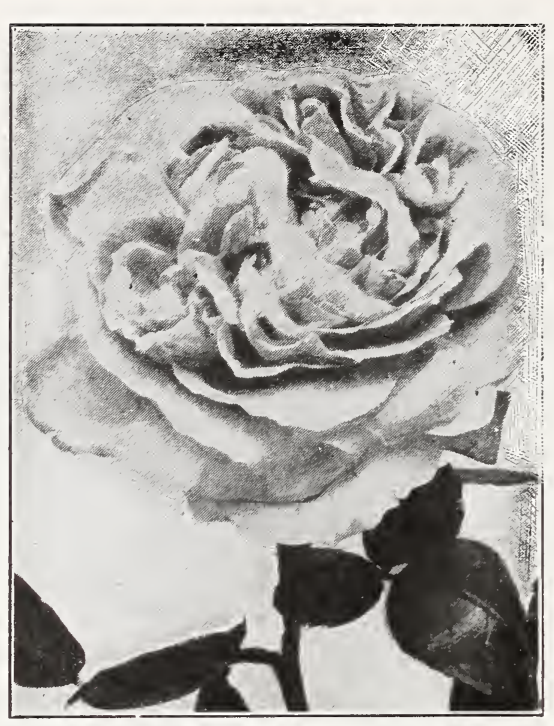

Meteor

Henry Martin-Rich, glossy pink, tinged with crimson; large globular flowers, full, sweet and finely mossed.

Iuxemburg_Clear, deep crimson, large, very sweet and mossy.

Perpetual white-Pure white, blooms in clusters, double, beautiful, vigorous.

\section{MISCELLANEOUS ROSES}

Venus-Flowers are bright glowing crimson, fully double. The plant is branching in habit, forming a fine, compact bush. One of the most vigorous mosses with splendid foliage.

Clothilde Soupert-Outer petals pearl white, shading to a center of rosy pink; the flowers are very double and handsomely formed. A grand free-flowering rose, fine for bedding or pot culture.

Crimson Baby Rambler-Crimson flowers in broad clusters, like those of the Crimson Rambler; a compact bush about two feet high. One of the finest bedding roses ever introduced.

Pink Baby Rambler-This has all the characteristics of the Crimson, but is loaded with great clusters of bright pink roses.

Kaiserin Augusta Victoria - Creamy white and sweetly fragrant; buds are large and pointed and flowers very full and large. Very hardy and continuous bloomer.

LaFrance-Flowers a delicate silvery rose, often silvery pink with peach shading; very large, very double and of superb form. The sweetest and most useful of all roses; flowers continually throughout the season and is deservedly a favorite with many rose growers.

Meteor-A rich, dark, velvety-crimson, everblooming rose. Flowers are of good size, very double and perfect in shape, either as buds or when fully opened. Plant is vigorous and remarkably free-flowering.
Excellent for pot culture and best of all the Hybrid Teas to bed for summer cut flowers as it retains its color well even in the hottest weather.

\section{CLIMBING ROSES}

Baltimore Belle-Pale blush, nearly white, very double. Blooms in large clusters late in the season, one of the best white climbers.

Marechal Neil-Beautiful canary yellow, large, full, globe-shaped flowers of delightful fragrance. Free-flowering; one of the finest yellow tea-scented roses yet introduced.

Prairie Queen-Bright canary yellow, compact and globular flowers; a rapid climber; hardy and one of the best.

Seven Sisters-Crimson, changing all shades to white, flowers are borne in clusters; one of the old fashioned sorts.

Thousand Beauty Rose-A new climbing rose, producing on the same bush so many different colored flowers that it is impossible to describe the variations, hence the very fitting name. Blooming profusely from beginning of June until last of July.

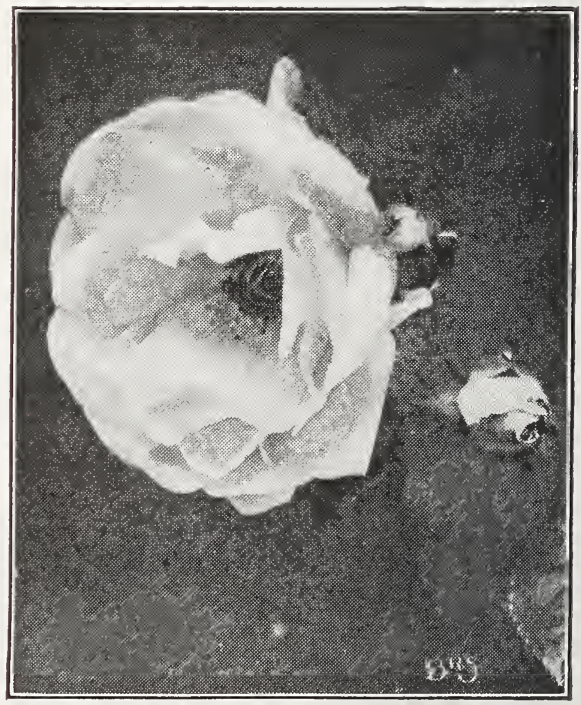

Thousand Beauty

Colors run from tender rose to bright rose and carmine with white and yellow tints showing a strong grower and hardy.

\section{RAMBLER ROSES}

Crimson-The famous crimson clustered climber, so extremely effective when grown on pillars and trellis. The flowers are grown in pyramidal panicles, each carrying thirty to one hundred blooms and over; the individual flowers are from one to one and one-half inches in diameter and remain in perfect condition a long time. The plant is a vigorous grower, making shoots from eight to ten feet long in a season.

Dorothy Perkins-Clear, shell-pink, flowers borne in large clusters of twenty-five 
to thirty, sweetly scented, full and double with crinkled petals. Foliage stays on a long time.

Philadelphia-Flowers deep rich crimson, more intense than the Crimson Rambler, with larger tresses of flowers which are perfectly double; the color does not fade and the clusters completely cover the bush. Vine is very hardy and a strong grower.

Yellow Rambler-A clear decided yellow, flowers of medium size in immense clusters, very sweet scented; hardiest of all yellow climbing roses. It is a rampant grower, well established plants often making a growth of ten to twelve feet in a season.

\section{TREE ROSES}

The Tree Roses are grafted on hardy stems 4 to 5 feet high, and thus form tree shapes. When in full bloom they are very handsome and are becoming more popular every vear as the demand for formal gardens grows. It is very necessary to have varieties which will lend them-

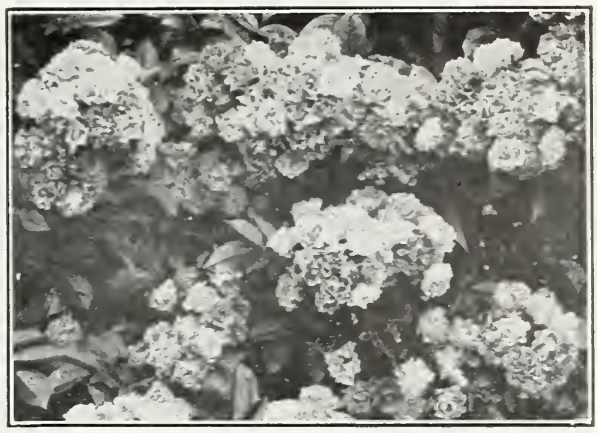

Crimson Rambler

selves to the severe pruning and training necessary to produce the tree form. and in this shape we offer only the Hybrid Perpetual or hardy class, with flowers of white, pink, scarlet and crimson.

\section{HARDY PERENNIALS}

Asters-Bloom in late fall in great profusion, perfectly hardy, and are to be had in almost all colors, plants growing 3 to 4 feet high.

Chrysanthemum (Hardy Pompon)-This class of beautiful plants is now so universally popular for out-door bedding, and justly so. They produce a lavish profusion of blooms, giving color, life and beauty to the garden at a time when other plants have been nipped by frost. Ther are quite hardy, but it is well to give a slight covering of leaves or manure during winter. Grow from 2 to 3 feet high.

Daisy, shasta-Large snowy-white flowers, 4 inches across; in bloom all summer; a good cut-flower variety.

Hibiscus (Militaris)-Strong growing 4 to 6 feet high, with white, blush, or pale rose flowers, with purple eye; blooming in August and september.

Hollyhocks-Few hardy plants combine as many good qualities as the Hollyhock.

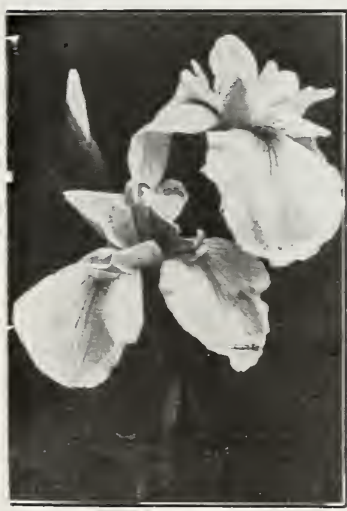

Japanese Iris

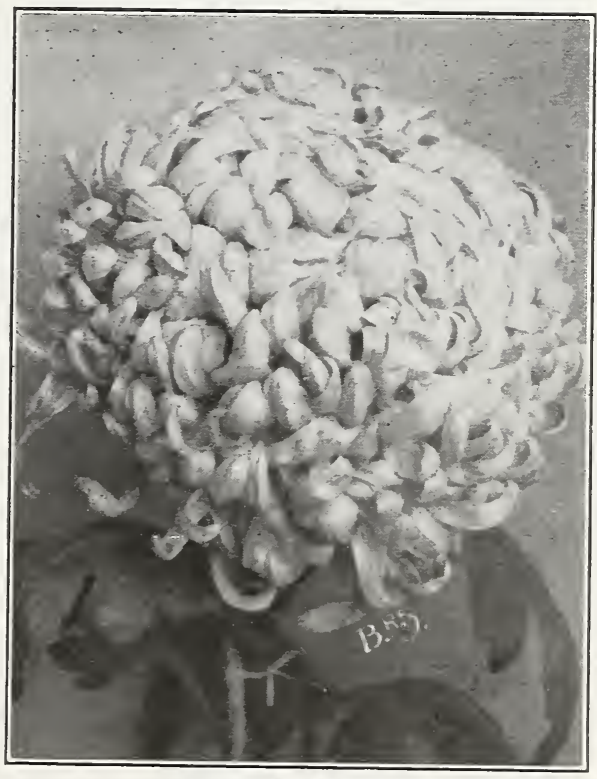

Chrysanthemum v shades of yellow, c rim son, For planting in rows or groups on the lawn, or ing interspersshrubbery, they are invaluable. The flower's form perfect rosettes rose

The Hollyhock requires a rich, deep soil, weil drained and will repay in quality and elesance of bloom any extra care. A slight protection in winter will be beneficial.

Iris Germanica (German Iris)-This group blooms in May with wonderful combinations of coloring: leaves broad, swordlike. We have an assortment of the best sorts.

Iris Kaempferi (Japan Iris)-The Japanese Iris should be planted in a somewhat cool, moist situation. and in rich soil. Its flowers, in late June and Julv, are quite distinct from those of all the varieties, and will compare favorably with some of the exotic orchids. We have a gocd assurtment of the best rarieties. 

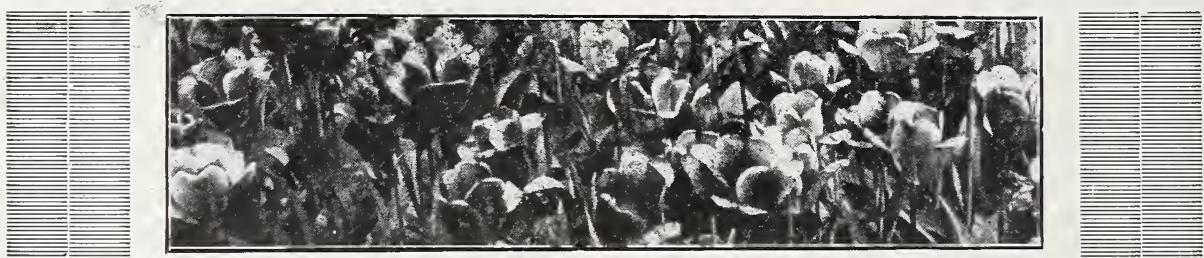

A Bed of Tulips

\section{HARDY BULBS}

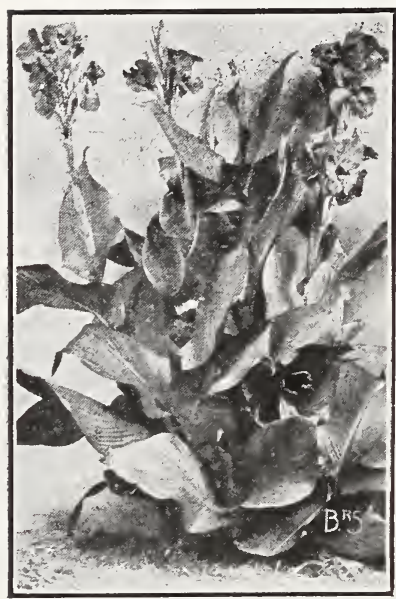

Cannas

Crocus-These are delicate and tasteful in form and varied and gay in color. Until the flowering of the Hyacinth, and through the most changeable and unpleasant of the spring weather, the garden depends almost alone upon the Crocus for its brightness. Plant the bulbs in autumn about 3 inches apart and cover with 2 inches of soil. Cover in fall with a little straw or coarse manure to keep the bulbs from being thrown out by the frost.

Fyacinths-Among all the bulbs used for winter flowers, the Hyacinth stands foremost. Flowers may be produced by placing the bulbs in a glass filled with water or placed in pots or boxes in soil; colors, blue, red, white with various shades.

\section{CANNAS}

Austria-A fine variety of the orchid-flowered type; large, handsome foliage, canary-yellow blooms.

Black Beauty-Small, red bloom; rich bronze foliage. Best of all the red-leaved sorts.

Florence Vaughan-Flowers of the most brilliant golden yellow, dotted with brightest scarlet.

\section{NARCISSUS}

Some varieties bloom as early as the Crocus. The flowers assume many forms and present many charming combinations of white, gold, primrose, orange, sulphur, and pure yellow. Some are quite fragrant; all very hardy, except the clustered Polyanthus. Double and single.

\section{PEONIES}

Charlemagne-Creamy white, center tinted lilac; very large and late.

Duke of wellington-Ivory-white, with creamy center. Very large and double.

Festiva Maxima-Extra large; white, center petals tipped carmine.

Golden Harvest-Creamy pink; very large and fragrant.

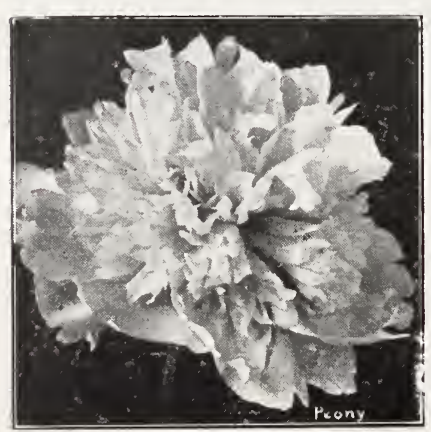

Jeanne d'Arc - Exquisitely scented, large flowers. Lilac-pink guards and tufted center, body soft yellow.

\section{DAHLIAS}

These showy and pretty flowers are very popular. One of the showiest of all

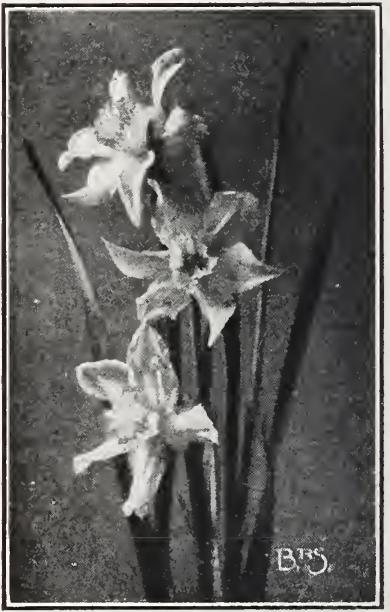

Narcissus bloom until stopped by frost. Flowers are most perfect and of beautiful form. Colors numerous. Before freezing weather, dig up plants and store in a frost-proof cellar.

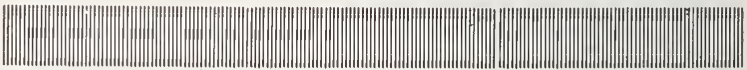

Peony

Printed By The Benton Review Shop, Fowler, Indiana. 


\section{AS MOST OF OUR BUSINESS IS DONE BY MEANS OF MAIL ORDERS, THE FOLLOWING SUGGESTIONS WILL BE OF BENEFIT}

1. It is advisable to send in your orders early, particularly if long transportation is necessary, and thus we shall be prepared to ship early.

2. Write your orders plainly on a separate piece of paper (use Order Sheet enclosed), and not in body of letter. State definitely varieties, age, size and number, whether standard or dwarf, and route by which you wish the goods shipped.

3. All orders from unknown parties should be accompanied by cash or satisfactory reference.

4. We are in no case responsible for loss or damage to goods in transit. Our responsibility ceases on delivery to shipping agents.

5. If selection of varieties is left to us, we will select according to our best judgment and long experience. Where varieties are specified we will substitute, for such as may not have, kinds equally good and ripening at the same season, unless otherwise ordered.

6. In case of any mistake on our part, immediate notice should be given, so that it may be rectified or explained.

\section{THE WAY WE DO BUSINESS}

We aim to keep fully abreast of an enlightened and cultivated taste, in the introduction of new and valuable varieties of fruit, and novelties and valuable acquisitions in ornamentals. Accepting with pleasure everything that has real merit, we shall with equal readiness discard and discountenance the sale of worthless humbugs.

We give to our packing and shipping careful personal supervision, and, to still further protect our patrons as well as ourselves against loss in this direction, we employ the most skilled and competent hands to assist us.

By careful consideration of the wants of our trade, and faithful attention to business, we hope to continue to merit and receive a share of the patronage of lovers and buyers of choice fruits and ornamentals.

Consult our list, and, if anything you want is not found, let us know and we will try to get it for you.

\section{ADVICE TO PLANTERS}

Select thrifty young trees in preference to old or very large ones; the roots are more tender and fibrous, and they bear transplanting better and are far more apt to live; they can also be more easily trimmed and shaped to any desired form, and in the course of a few years will usually outstrip the older ones in growth.

Choose good, rich soil, with sufficient slope to the north or northeast, if convenient. Avoid sandy bottoms or knobs and points. Prepare the soil thoroughly, lay off in rows north and south with the plow, as deeply as possible; it will save half the digging. Every 16 to 20 feet in the row, dig a hole deep enough so that the tree will sit a little deeper than it stood in the nursery, and large enough to admit all the roots spread out in their natural position.

Planting-Never expose the roots to the sun and wind more than can be helped. Cut off broken and bruised roots, and shorten the tops to correspond with the roots. Plant the heaviest part of the top toward the southwest, and lean the tree the same way at an angle of about 45 degrees. Sift the soil in around the roots carefully, filling in all crevices; when well covered, tramp it down solidly; if very dry, pour in some water, and, after it has soaked away, fill in the top with loose soil to prevent baking. After the trees are nicely started, a mulch of straw or litter will be beneficial.

Cultivate your young trees and shrubs at least as well as you do your corn, up to the first of July, and then let them ripen up for the winter. Pumpkin vines make an excellent shade for the orchard soil.

Rows-Let them be as far apart as your conscience will allow.

Frozen Stock-If received in that condition, place in a cool cellar, and do not disturb until they are completely thawed out.

\section{ENTOMOLOGIST'S CERTIFICATE OF NURSERY INSPECTION}

We are prepared to furnish, with each shipment of nursery stock, a certificate from our State Entomologist showing that our nurseries have been inspected according to law. We have already made arrangements with the proper officers or boards of the states requiring that certificates be furnished them. 


\section{These are Some of the Medals, Diplo- mas and Awards We Have Received:}

First Premium and Award of Merit at New Orleans Exposition years ago.

First Premium and Diploma for largest and best collection of Apples, Plums and Pears at Iowa State Fair, in 1889.

"Sweepstakes" for largest and best collection of varieties of fruits adapted to and grown at Iowa State Fair, in 1891.

First Premium for Stoddard Plum, as the largest American variety exhibited at the World's Fair, Chicago, in 1893.

First Premium for Largest Collection of American Plums at Iowa State Fair, in 1895 , our exhibit at this time containing over forty-five varieties.

Bronze Medal and Diploma for largest exhibit of Apples and Plums from Iowa, at Trans-Mississippi and International Exposition, in 1898.

Gold Medal and Diploma for largest display of Cherries and Plums from Iowa, at Louisiana Purchase Exposition, St. Louis, 1904.

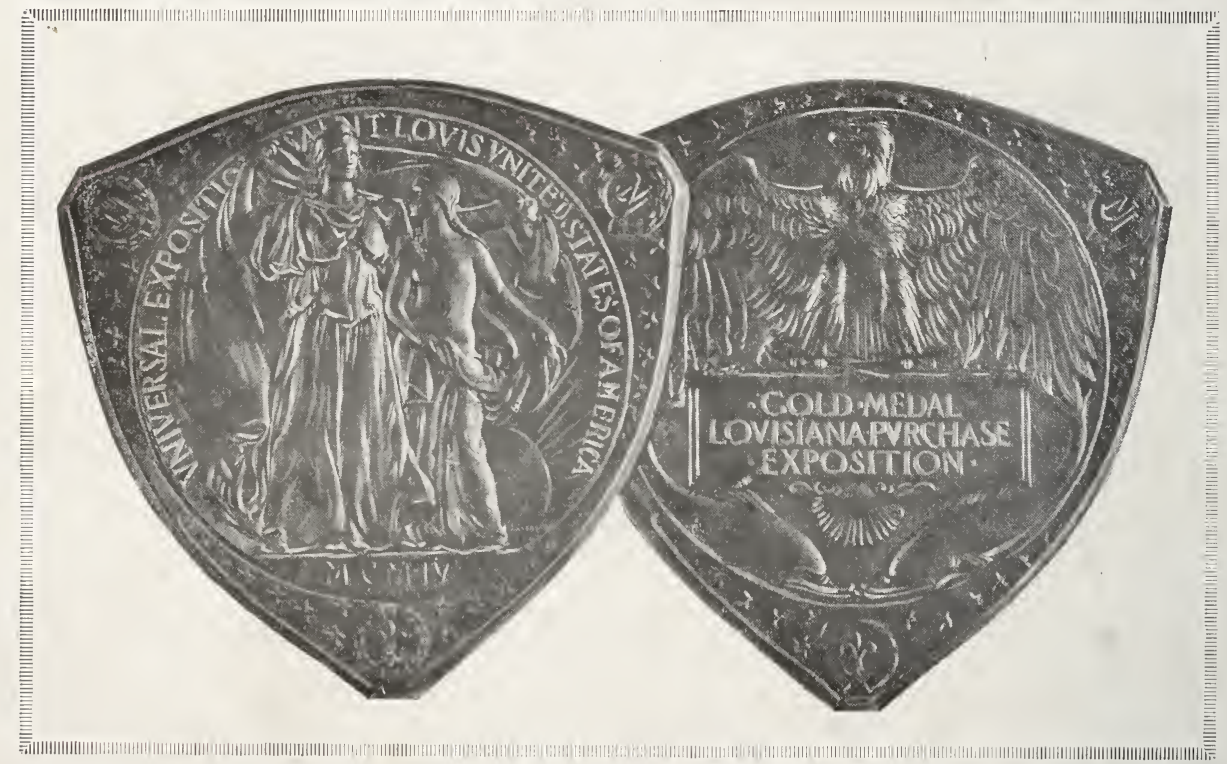

